\title{
Depleted subcontinental lithospheric mantle and its tholeiitic melt metasomatism beneath NE termination of the Eger Rift (Europe): the case study of the Steinberg (Upper Lusatia, SE Germany) xenoliths
}

\author{
Anna Kukuła $^{1}$ - Jacek Puziewicz ${ }^{1}$ - Magdalena Matusiak-Małek ${ }^{1}$. \\ Theodoros Ntaflos ${ }^{2} \cdot$ Jörg Büchner ${ }^{3}$ • Olaf Tietz ${ }^{3}$
}

Received: 13 March 2015 / Accepted: 4 September 2015 /Published online: 22 September 2015

(C) The Author(s) 2015. This article is published with open access at Springerlink.com

\begin{abstract}
The ca. 30 Ma Steinberg basanite occurs at the NE termination of the Eger (Ohře) Rift in the NW Bohemian Massif, Central Europe, and belongs to the Cenozoic alkaline Central European Volcanic Province. The basanite hosts a suite of mantle xenoliths, most of which are harzburgites containing relatively magnesian olivine (Fo 90.5-91.6) and Alpoor (0.04-0.13 a pfu) orthopyroxene (mg\# 0.90-0.92). Some of these harzburgites also contain volumetrically minor clinopyroxene (mg\# 0.92-0.95, Al 0.03-0.13 a pfu) and have U-shaped LREE-enriched REE patterns. The Steinberg harzburgites are typical for the Lower Silesian - Upper Lusatian domain of the European subcontinental lithospheric mantle. They represent residual mantle that has undergone extensive partial melting and was subsequently affected by mantle metasomatism by mixed carbonatite-silicate melts. The Steinberg xenolith suite comprises also dunitic xenoliths affected by metasomatism by melt similar to the host basanite, which lowered the Fo content in olivine to $87.6 \%$. This metasomatism happened shortly before xenolith entrainment in the erupting lava. One of the xenoliths is a wehrlite (olivine Fo $73 \%$, clinopyroxene $\mathrm{mg} \# 0.83-0.85$, subordinate orthopyroxene mg\# $0.76-0.77)$. Its clinopyroxene REE
\end{abstract}

Editorial handling: L. Fedele

Anna Kukuła

anna.kukula@ing.uni.wroc.pl

1 Institute of Geological Sciences, University of Wrocław, Wrocław, Poland

2 Department for Lithospheric Research, University of Vienna, Wien, Austria

3 Senckenberg Museum of Natural History Görlitz, Görlitz, Germany pattern is flat and slightly LREE-depleted. This wehrlite is considered to be a tholeiitic cumulate. One of the studied harzburgites contains clinopyroxene with similar trace element contents to those in wehrlite. This type of clinopyroxene records percolation of tholeiitic melt through harzburgite. The tholeiitic melt might be similar to Cenozoic continental tholeiites occurring in the Central European Volcanic Province (e.g., Vogelsberg, Germany).

\section{Introduction}

Mantle xenoliths, brought to the surface by volcanic eruptions, are common in the alkaline lavas of the Cenozoic Central European Volcanic Province (CEVP). Their "sampling" by the erupting lavas is accidental, and their position in the vertical profile of the subcontinental lithospheric mantle (SCLM) is usually difficult to ascertain. However, the xenoliths are found in numerous places, and therefore studies of these mantle rocks from individual sites provide information about the underlying mantle Comparision of the data on the regional scale enables us to define the lateral lithological variation of the lithospheric mantle.

Recent studies have shown that the subcontinental lithospheric mantle is heterogeneous (e.g., Hofmann 2007; Pearson et al. 2003 and references therein). The lateral inhomogeneity of the lithospheric mantle beneath Europe has already been documented by Downes (2001), and different lithological "domains" were identified in Massif Central (Lenoir et al. 2000). This inhomogeneity is caused by variable degrees of melt extraction as well as different styles and extent of metasomatism and is reflected in the isotopic composition (e.g., Downes 2001; Witt-Eickschen et al. 1998; Ackerman et al. 2007). The first modern study of upper mantle xenoliths from 
Lower Silesia (northern margin of Bohemian Massif) pointed out the depleted nature of the lithospheric mantle in this area and showed regional variations in the metasomatic history of the SCLM (Blusztajn and Shimizu 1994). In the eastern part (Lutynia locality) the mantle was metasomatized by carbonatite, while in the western part (Wilcza Góra, Pilchowice, Ksiegginki) metasomatism through alkaline silicate melt was suggested (Puziewicz et al. 2015 and references therein). Recent studies of Matusiak-Małek et al. (2014) and Puziewicz et al. (2015) have shown that the SCLM beneath Lower Silesia and Upper Lusatia is mostly harzburgitic, strongly depleted in aluminium, and probably constitutes a distinct refractory "domain" in the European SCLM. Recent studies of the SCLM beneath the Eger Rift (western part of the Bohemian Massif) also confirm its heterogeneity. Ackerman et al. (2013, 2015) showed that the degrees of melting and subsequent metasomatism differ between the SW extension of Eger Rift in NE Bavaria (Ackerman et al. 2013) and České Středohoři Volcanic Complex in the central part of the Rift. The Plešný site in the NE part of the rift (Ackerman et al. 2015) is located in the Lower Silesia - Upper Lusatia SCLM domain and fits well its depleted nature (Puziewicz et al. 2015).

In this paper we describe xenoliths found in the Steinberg Quarry near Görlitz at the Polish-German border. We show that most of these xenoliths fit well with the "refractory" nature of the Lower Silesia - Upper Lusatia domain. However, some xenoliths record percolation of tholeiitic melt which could have originated by melting of depleted lithologies in the SCLM.

\section{Geological setting and host rock characteristics}

The xenoliths described in this study come from the abandoned quarry Stadtwaldbruch at Steinberg near Ostritz (Fig. 1). The outcrop is situated within the Lausitz (Lusatia) Volcanic Field in the CEVP (Büchner et al. 2015). The Lausitz Volcanic Field is located on various geological units (Kozdrój et al. 2001; Büchner et al. 2015). Its northernmost and northeastern parts overlap Paleozoic anchimetamorphic sediments of the Kaczawa and Görlitz Synclinoriums and more to the south Cadomian granitoids and greywackes. The latter two basement units form the Lausitz Massif, within which Steinberg is situated. The quarry exposes a lava flow and a few remnants of a small volcano (scoria cone?). The eruption centre was probably situated on the north-eastern edge of the quarry. The basanitic lavas probably ponded within the crater and formed a lava lake, which fed lava flows (Büchner et al. 2015). The lava reaches a thickness of up to $20 \mathrm{~m}$. At the contact between lava and the underlying granodiorite, blocky peperitic structures were formed (Tietz et al. 2013).

The basanite locally contains numerous, small (up to $8 \mathrm{~cm}$ in diameter) peridotitic xenoliths. The lava is an olivine- augite basanite which has yielded a K-Ar age of $30.3 \pm 2 \mathrm{Ma}$ (Pushkarev 2000). It has microlitic structure with olivine and augite phenocysts and plagioclase- and clinopyroxene-laths as microliths, embedded in the nepheline + opaques groundmass. Chemical analyses (Büchner et al. 2015) reveal contamination of the lava by xenoliths, indicated in decreasing $\mathrm{MgO}, \mathrm{Cr}$ and $\mathrm{Ni}$ contents from proximal $(13.1 \mathrm{wt} . \% \mathrm{MgO})$ to distal (10.2 wt.\% MgO) parts of the lava flow. The xenolith-rich lava contains 42.2 - 42.3 wt. $\% \mathrm{SiO}_{2}, 3.1$ wt. $\% \mathrm{Na}_{2} \mathrm{O}$ and 1.1 wt. $\%$ $\mathrm{K}_{2} \mathrm{O}$ and has the composition of basanite in the Total Alkali Silica diagram. The Steinberg basanite is enriched in trace elements relative to primitive mantle (McDonough and Sun 1995), and its Rare Earth Elements (REE) pattern shows a constant increase from $\mathrm{Lu}$ to $\mathrm{Nb}\left(\mathrm{La}_{\mathrm{N}} / \mathrm{Lu}_{\mathrm{N}}=26.6\right.$; Appendix Table 1).

\section{Analytical methods}

In this study we have analyzed 11 samples, using $150 \mu \mathrm{m}$ thick sections. Modal composition of the samples was calculated by point counting on high-resolution images of sections using the JMicroVision software. This software was also used on Back Scattered Electrons (BSE) images to determine volume proportions of phases in symplectites.

Electron microprobe analyses were conducted at the Department of Lithospheric Research at the University of Vienna with a Cameca SX100 electron microprobe. Acceleration voltage was $15 \mathrm{kV}$, sample current $25 \mathrm{nA}$, counting times on peak positions were $20 \mathrm{~s}$. In order to improve the accuracy and detection limits for $\mathrm{Ca}$ and $\mathrm{Ni}$ in olivine, the counting time on the peak position was set to $40 \mathrm{~s}$ for these elements. The PAP matrix correction method was applied.

Concentrations of trace elements in clino- and orthopyroxene were determined in situ by laser ablation inductively coupled mass spectrometry (LA ICP-MS) using a Resonetics RESOlution M50 excimer laser (ArF) coupled with a Thermoelectron XSeries2 ICP-MS system at the Institute of Geological Sciences of the Polish Academy of Sciences, Kraków Research Centre. Energy density of 8 $10 \mathrm{~J} \mathrm{~cm}^{-2}$ at a repetition rate of $5-10 \mathrm{~Hz}$ was applied for a circular ablation spot of $45-80 \mu \mathrm{m}$ diameter. Gas blank was analyzed for $20 \mathrm{~s}$ prior to each $45 \mathrm{~s}$ ablation, which was followed by $30 \mathrm{~s}$ washout. Sample runs were bracketed by measurements of NIST612, NIST610 glasses (reference values of Jochum et al. 2011 were adopted); MPI DING (MPI3, ML3-B, GOR128-G, GOR132-G) glasses were measured as secondary standards. Ca content analysed by electron microprobe was used as an internal standard. Data processing was performed using Glitter 4.0 software (van Achterberg et al. 2001). The accuracy of the results is typically below $12 \%$ for most of the elements, for $\mathrm{Nb}$ and $\mathrm{Ta}$ it is \pm 20 $31 \%$, for $\mathrm{Y}$ it is $\pm 7-19 \%$ and for $\operatorname{Pr} \pm 9-22 \%$. The analyses of orthopyroxene I are contaminated by the fine 


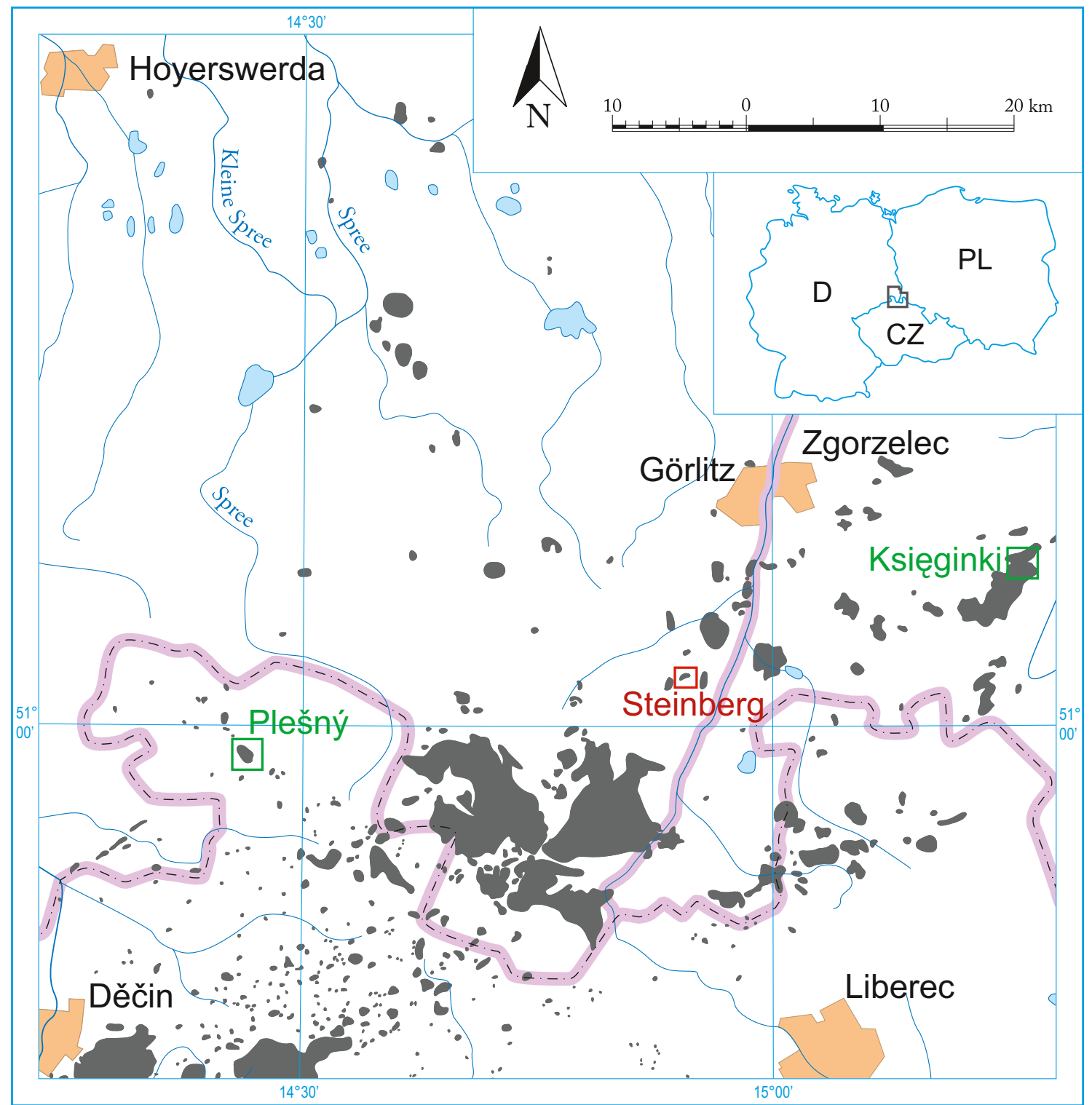

Fig. 1 Location of Steinberg quarry and occurrences of Cenozoic basalts of Central European Volcanic Province (based on map of Sawicki 1995)

clinopyroxene II intergrowths, whose size was too small to allow the "cleaning" of the analyses during data reduction (for method description see Matusiak Małek et al. 2014).

The whole rock composition of host rock from Steinberg was analyzed for 2 samples, coming from the xenolith-rich part of lava, in ACME analytical laboratory (Vancouver, Canada) by ICP-MS (LF200, AQ200 procedures).

The Morimoto (1989) classification of pyroxenes is used. Spinel compositions were recalculated on the basis of three cations, with $\mathrm{Fe}^{3+}$ and $\mathrm{Fe}^{2+}$ calculated by charge balance (Deer et al. 1993). The cr-number or cr\# denotes the atomic ratio of $\mathrm{Cr} /(\mathrm{Cr}+\mathrm{Al})$, and $\mathrm{mg}$-number or $\mathrm{mg} \#$ stands for atomic $\mathrm{Mg} /\left(\mathrm{Mg}+\mathrm{Fe}^{2+}+\mathrm{Fe}^{3+}\right)$. Forsterite ( $\mathrm{Fo}$ ) content in olivine is calculated as $100 * \mathrm{Mg} /(\mathrm{Mg}+\mathrm{Fe}+\mathrm{Mn})$ per formula unit (a pfu). The trace elements were normalized to primitive mantle (PM) using the values of McDonough and Sun (1995). The titanium and europium anomalies were calculated using formulas: $\mathrm{Ti} / \mathrm{Ti}^{*}=\mathrm{Ti}_{\mathrm{N}} /\left(\left(\mathrm{Eu}_{\mathrm{N}}+\mathrm{Gd}_{\mathrm{N}}\right) / 2\right)$ and $\mathrm{Eu} / \mathrm{Eu}^{*}=\mathrm{Eu}_{\mathrm{N}} /$ $\left(\left(\mathrm{Sm}_{\mathrm{N}}+\mathrm{Gd}_{\mathrm{N}}\right) / 2\right)$, respectively. Mineral abbreviations are: $\mathrm{Ol}$ (olivine), Opx (orthopyroxene), Cpx (clinopyroxene) and Spl (spinel), Fsp (alkali feldspar), Pl (plagioclase), Sul (sulfide).

\section{Petrography of xenoliths}

Steinberg xenoliths are typically oval, from 3.0 to $6.5 \mathrm{~cm}$ in diameter, some are fissured. Contacts with the host basanite are sharp. Almost all the xenoliths have the composition of 
harzburgite (Fig. 2) and are formed of three kinds of minerals: (1) primary major rock-forming ones (Ol I, Opx I, Cpx I, Spl I; Fig. 3a, b), (2) lamellae and intergrowths in (1): Cpx II, Spl II (Fig. 3c), and (3) intergranular, fine-grained aggregates formed of Ol III, Opx III, Cpx III and Spl III, Fsp (Fig. 3d, e), and phases post-dating the primary phases: vermicular clinopyroxene III rims (typically $2-5 \mu \mathrm{m}$ wide, Fig. 3f, g) enveloping clino- and orthopyroxene I, interstitial clinopyroxene III (Fig. 3h, i). In some of the xenoliths, spinel I is absent or it is present in small amounts (Appendix Table 2). The harzburgites are mostly protogranular (sensu Mercier and Nicolas 1975) and show neither foliation nor lineation. Primary minerals are anhedral, usually $1.5-4 \mathrm{~mm}$ in diameters, extremely up to 6-7 mm (Fig. 3a). Interstitial aggregates are typically rounded with diameter up to $1 \mathrm{~mm}$ and consist of an- to subhedral grains up to $130 \mu \mathrm{m}$ in size (Fig. 3d). Xenoliths 3323 and 3334 are characterized by presence of $50 \mu \mathrm{m}$ thick aggregates of olivine III, clinopyroxene III, spinel III, feldspar and glass occurring along grain margins.

Olivine I forms fractured grains $(3-4 \mathrm{~mm}, \max 7 \mathrm{~mm})$, which in xenoliths 3324 and 3337-2 show kink banding. Orthopyroxene I occurs as large grains (up to $6 \mathrm{~mm}$ ) typically containing spinel II or clinopyroxene II lamellae in core parts. Clinopyroxene I occurs as separate, locally randomly perforated, angular to rounded $<1.5 \mathrm{~mm}$ grains of uneven margins and as part of spinel I - clinopyroxene I clusters (Appendix Table 2, Fig. 3b) which reach maximum size of ca. $5 \mathrm{~mm}$. Most of clinopyroxene I grains contain single $\mu \mathrm{m}$ lamellae of spinel II. Spinel I forms irregular grains, exceeding $1 \mathrm{~mm}$ in length, and as part of spinel I - clinopyroxene I clusters.

Harzburgite 3326 contains a ca. $2.5 \mathrm{~mm}$ cluster of spinel I, and clinopyroxene I, which also contains clinopyroxene III,

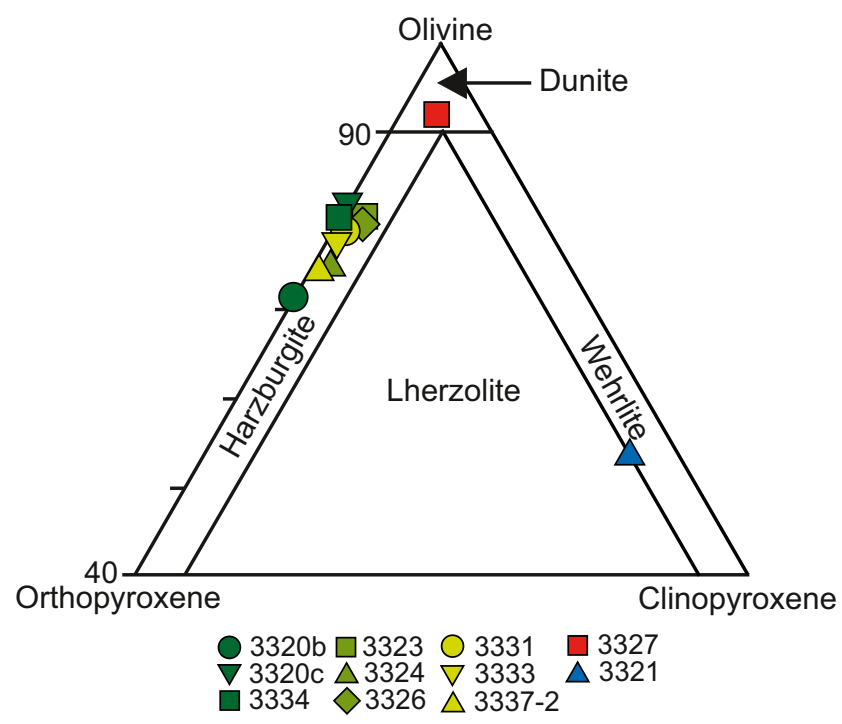

Fig. 2 Modal composition of xenoliths shown in the olivineorthopyroxene-clinopyroxene ternary diagram olivine III and orthopyroxene III (Fig. 4). Clinopyroxene I is rimmed by spongy clinopyroxene III, which occurs also along spinel grains. Amoeboid remnants of orthopyroxene III and olivine III, up to $200 \mu \mathrm{m}$, occur in clinopyroxene I and III (Fig. 4).

Intergranular aggregates of olivine III, orthopyroxene III, clinopyroxene III, glass, alkali feldspar and/or plagioclase occur in some xenoliths (Appendix Table 2). Olivine III forms rounded, elongated or irregular 50-80 $\mu \mathrm{m}$ (max. $125 \mu \mathrm{m})$ grains, locally with ragged edges. Clinopyroxene III forms small (max. $80 \mu \mathrm{m}$ in length), irregular grains, sometimes spongy, and thin (few $\mu \mathrm{m})$ rims on orthopyroxene III. Spinel III grains $(<40 \mu \mathrm{m})$ are sparse and form skeletal, subhedral crystals (Fig. 3d). Orthopyroxene III occurs only in xenolith 3334 as max. $100 \mu \mathrm{m}$ grains surrounded by clinopyroxene rims a few $\mu \mathrm{m}$ thick. Glass or alkali feldspar occurs between olivine, clinopyroxene and spinel. The wehrlitic xenolith (3321) contains two types of symplectites: S1 - consisting of green spinel and clinopyroxene and S2 - consisting of relics of green spinel, orthopyroxene, alkali feldspar and olivine (Fig. 3e). Shape of green spinel in symplectite S2 mimics that of spinel in symplectite S1, and textural relationships show that symplectite $\mathrm{S} 2$ is the product of replacement of symplectite $\mathrm{S} 1$ by the intergranular aggregates. The two types of symplectites show sharp contact. This xenolith is exceptional because of commonly occurring sulfides. Sulfide grains occur either interstitially or are poikilitically enclosed in primary silicates. Large grains $(200-500 \mu \mathrm{m})$ have irregular shapes and are typically interstitial, while smaller (up to $200 \mu \mathrm{m}$ ) oval grains are enclosed or occur in aggregates. Sulfides also occur in intergranular aggregates (Fig. 3e).

Harzburgite 3326 and dunite 3327 contain interstitial, oval to angular crystals of clinopyroxene III reaching from 30 to $70 \mu \mathrm{m}$, which are locally perforated and texturally inhomogeneous (Fig. 3h). Between the crystals of clinopyroxene III, oval grains of olivine III (60-160 $\mu \mathrm{m}$ long), scarce spinel III and amoeboid remnants of orthopyroxene I (?) occur (Figs. $3 \mathrm{i}$ and 4). In xenolith 3326 clinopyroxene I is surrounded by perforated clinopyroxene III. Vermicular rims of clinopyroxene III enveloping orthopyroxene I in those xenoliths are extremely well developed and reach 50-100 $\mu \mathrm{m}$ (Fig. 3f, g). The rims are spongy and locally enclose olivine III and glass. Contact between the spongy and interstitial clinopyroxene III is transitional and often underlined by small, amoeboid crystals of orthopyroxene I (Fig. 3i).

\section{Mineral chemical composition}

The content of forsterite in olivine I in most xenoliths is 90.5 $91.6 \%$ (Fig. 5a). This corresponds to the "A" harzburgites defined by Matusiak-Małek et al. (2014) in Krzeniów. Thus, we follow the classification of Matusiak-Małek et al. (2014) 

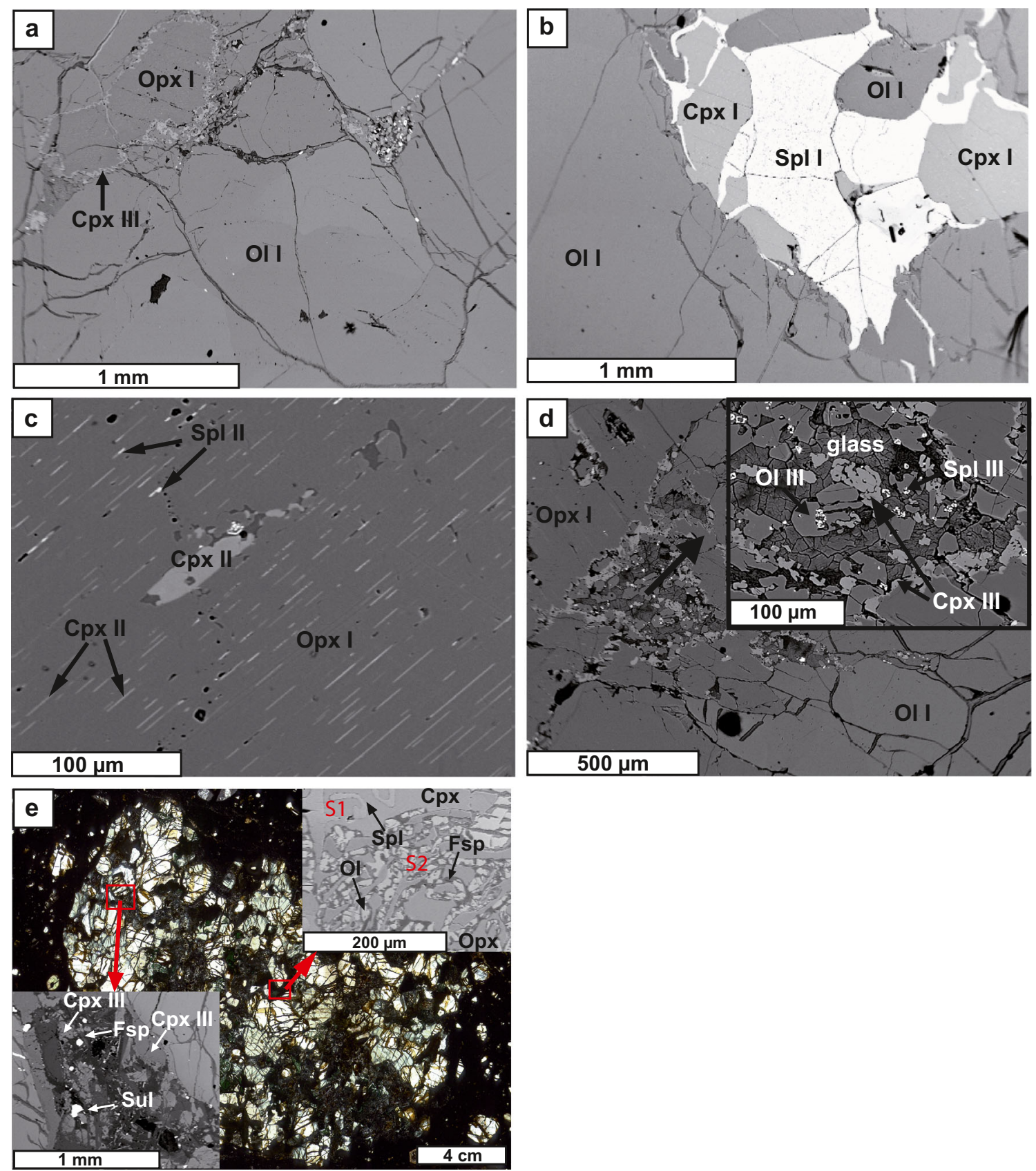

Fig. 3 Relationships between minerals in Steinberg xenoliths. (a) Texture of harzburgite 3334 (BSE image); (b) Clinopyroxene I - spinel I cluster in harzburgite 3324 (BSE image); (c) Clinopyroxene II and spinel II lamellae in orthopyroxene I (harzburgite 3320b, BSE image); (d) Fine-grained aggregate in harzburgite 3333 (BSE image); (e) Texture of wehrlite 3327 (plane polarised light image) with fine-grained aggregate

and denote those harzburgites as " $\mathrm{A}$ " ones. The dunite 3327 contains olivine I partly corresponding to the group " $\mathrm{A}$ " from Krzeniów, but most analysis plot in the compositional range for group " $\mathrm{B}$ " in Krzeniów (88.2-89.8 \% Fo) and thus we classify it as group " $\mathrm{B}$ ". The wehrlite 3321 containing relatively low-forsteritic olivine $(72.7-73.7 \% \mathrm{Fo})$ is classified as "C" type. and symplectite 1 and 2 (BSE images); (f) Texture of dunite 3327 (BSE image); (g) Orthopyroxene I grain with clinopyroxene III rim (dunite 3327, BSE image); (h) Olivine III grains embedded in interstitial clinopyroxene III (dunite 3327, BSE image); (i) Orthopyroxene III remnants in interstitial, perforated clinopyroxene III (harzburgite 3326, BSE image)

\section{Mineral major and trace element composition - harzburgites A}

Olivine I (Fo90.5-91.6) contains 0.35 to 0.48 wt. \% $\mathrm{NiO}$ (Appendix Table 3, Fig. 5a). Ca content in olivine I varies from that of microprobe detection limit (200 ppm) to ca. $800 \mathrm{ppm}$ (Fig. 5b). Orthopyroxene I has the composition of 

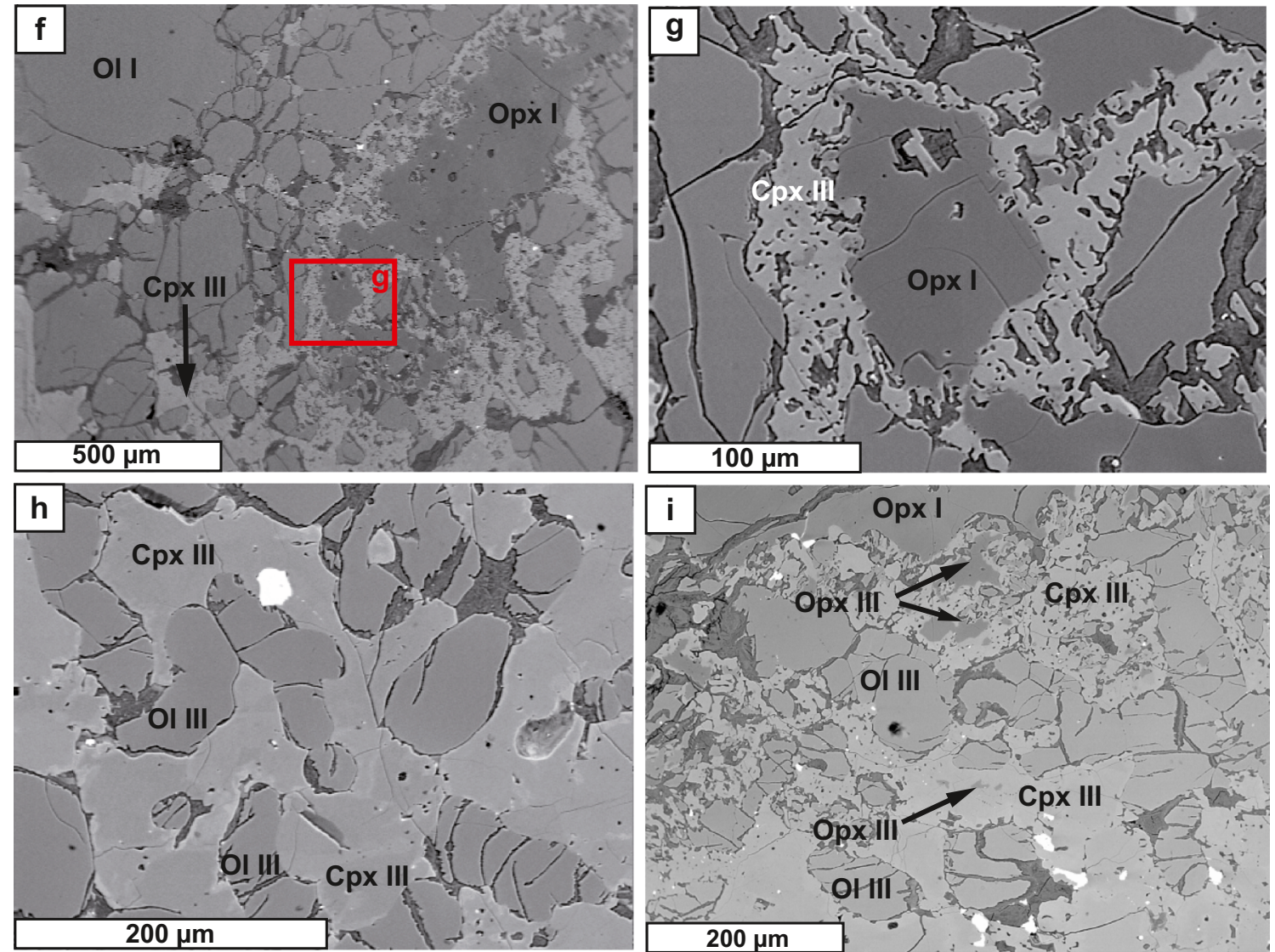

Fig. 3 (continued)

enstatite or Cr-, Al-enstatite, its mg\# varies from 0.90 to 0.92 , and $\mathrm{Al}$ content ranges from 0.04 to $0.13 \mathrm{a} \mathrm{pfu}$ (Fig. 6a, Appendix Table 4). Clinopyroxene I is diopside (Fig. 7a) of mg\# 0.92-0.95, Al 0.03-0.13 a pfu (Fig. 7b) and Ca 0.82 to 0.97 a pfu (Fig. 7c, Appendix Table 4). Mg\# and $\mathrm{Al}$ and $\mathrm{Cr}$ contents are negatively correlated in both ortho- and clinopyroxene (Figs. 6b and 7d). $\mathrm{Na}$ is negatively correlated with $\mathrm{Ca}$ in clinopyroxene (Fig. $7 \mathrm{c}$ ). $\mathrm{Mg}$ - number in spinel I varies between 0.62 and 0.67 , while chromium number ranges from 0.41 to 0.51 (Fig. 8, Appendix Table 5). Spinel I grain in harzburgite 3334 located near the fine-grained aggregate is characterized by lower mg\# (0.57-0.59) and higher cr\# $(0.50-0.54)$. Xenolith 3326 is characterized by spinel I with mg\# 0.62-0.67 and cr\# 0.47-0.51 (Fig. 8).

The primitive-mantle normalized Rare Earths Elements patterns of orthopyroxene I from harzburgites 3323, 3324, 3331 and 3337-2 are U-shaped (Fig. 9a) and strongly depleted $(\mathrm{La}=0.004-0.159 \times \mathrm{PM}, \mathrm{Tb}=$ from b.d.1. to $0.01 \times \mathrm{PM}, \mathrm{Lu}=$ 0.09-0.19 x PM). The second type of REE pattern (harzburgites 3334, 3320b. Figure 9b) is also U-shaped, but

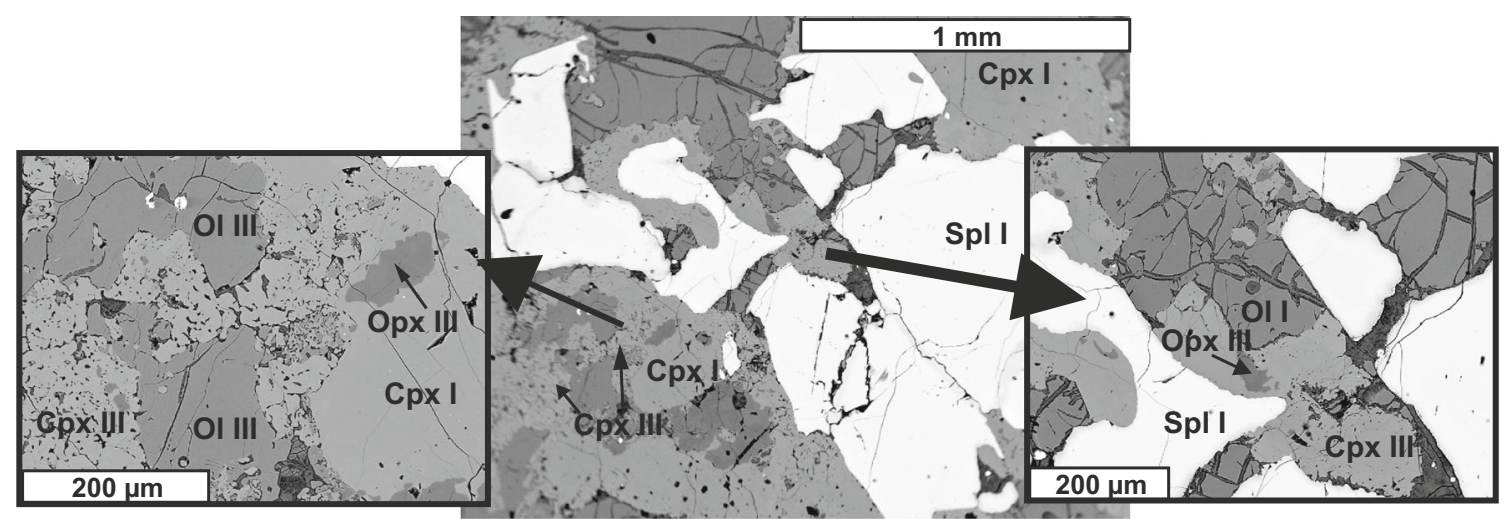

Fig. 4 Assemblage of spinel I, clinopyroxene I and III, olivine III and orthopyroxene III (harzburgite 3326, BSE images) 

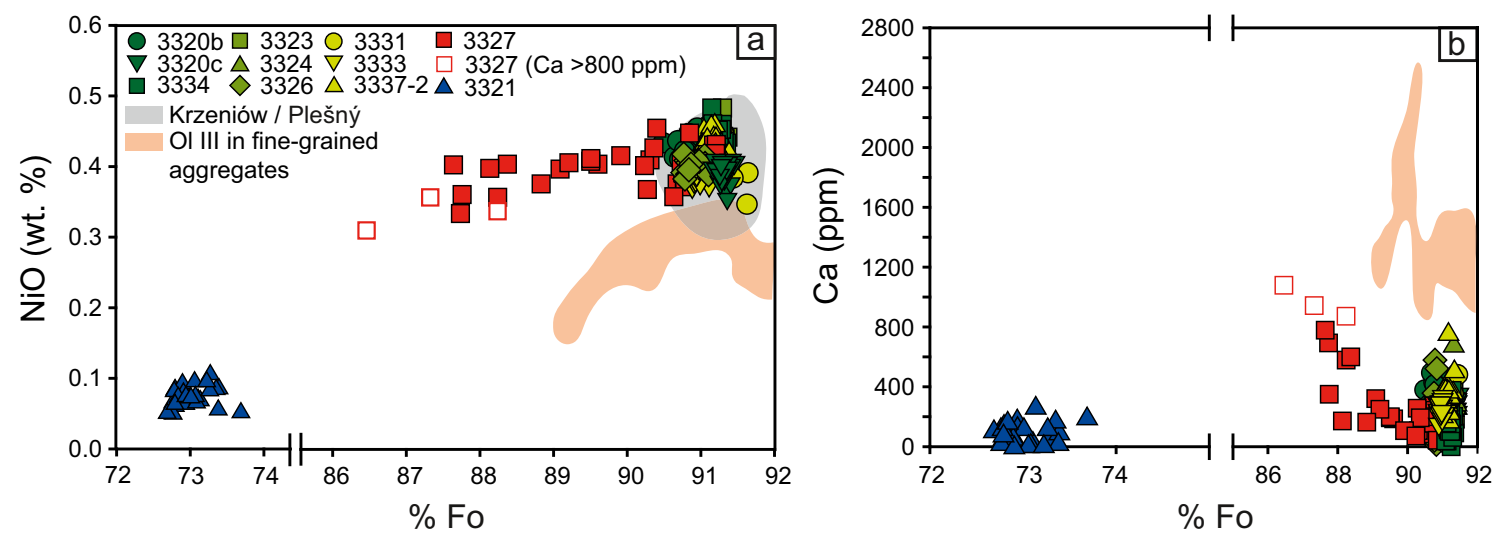

Fig. 5 Relationships between Fo and $\mathrm{NiO}$ (a) and $\mathrm{Ca}(\mathbf{b})$ contents in olivine. The field of olivine from the Krzeniów A xenoliths in (a) after MatusiakMałek et al. (2014), that of olivine from Plešný after Ackerman et al. (2015)

shallower and at higher REE contents $(\mathrm{La}=0.7-0.8 \times \mathrm{PM}$, $\mathrm{Tb}=0.04 \times \mathrm{PM}, \mathrm{Lu}=0.1-0.2 \times \mathrm{PM})$. The multi-trace element patterns of orthopyroxene of all group A harzburgites exhibit strong $\mathrm{Th}-\mathrm{U}$ and Ti positive and negative $\mathrm{Nb}-\mathrm{Ta}$ anomalies (Fig. 9c). The trace element contents are highly variable even in the scale of one thin section (Fig. 9d). Orthopyroxene I in harzburgite 3326 shows constant depletion from Heavy REE (HREE) to Light REE (LREE; Fig. 9e) and no positive Th-U and Ti anomalies (Fig. 9f).

Two types of primitive-mantle normalized clinopyroxene I REE patterns occur in group A xenoliths. The first one (harzburgites 3323, 3324, 3331, 3337-2) is U-shaped $\left(\mathrm{La}_{\mathrm{N}} / \mathrm{Lu}_{\mathrm{N}}=1.1-35.3, \mathrm{La}_{\mathrm{N}} / \mathrm{Sm}_{\mathrm{N}}=16.9-103.9\right.$; Fig. 10a, Appendix Table 6). LREE contents vary from below primitive mantle (xenoliths 3323, 3324) to above primitive mantle (xenoliths 3331, 3337-2; Fig. 10a) and are negatively correlated with $\mathrm{mg} \#$ of host clinopyroxene. This group is characterized by a zig-zag like pattern of spider diagram from $\mathrm{Hf}$ to $\mathrm{Rb}$ with elevated Th-U (Fig. 10b). A distinct $\mathrm{Zr}$-Hf negative anomaly is present in 3323,3324 and $3337-2$ clinopyroxene. In clinopyroxene from harzburgite $3331 \mathrm{Nb}$, Hf and Ti negative anomalies occur (Fig. 10b). The second type of REE pattern (harzburgite 3326; Fig. 10c) is nearly flat at HREE and MREE $\left(\mathrm{Gd}_{\mathrm{N}} / \mathrm{Lu}_{\mathrm{N}}=1.2-1.7\right)$, while LREE content is variable. In grains which do not form clusters with spinel, LREE are depleted $\left(\mathrm{La}_{\mathrm{N}} / \mathrm{Lu}_{\mathrm{N}}=0.38,0.43\right)$; LREE in cluster-forming clinopyroxene are higher and exceed primitive mantle values $\left(\mathrm{La}_{N} / \mathrm{Lu}_{\mathrm{N}}=12.4,0.7\right.$, Fig. $\left.10 \mathrm{c}\right)$. That is also reflected in trace element contents (Fig. 10d, Appendix Table 6). $\mathrm{Rb}, \mathrm{Ba}$, Th and $\mathrm{U}$ contents are lower, below primitive mantle in clinopyroxene which do not form clusters with spinel, and respectively higher (at the level of primitive mantle) in clinopyroxene forming the clusters.

Lamellae of clinopyroxene II in orthopyroxene I are characterized by $\mathrm{mg} \#=0.91-0.92$ and $\mathrm{Al} 0.11-0.20$ a pfu
(Appendix Table 4). Chromium number in spinel II lamellae in orthopyroxene I is 0.23 and 0.49 (only two analyses) and mg- number is 0.53 and 0.74 , respectively, while spinel II
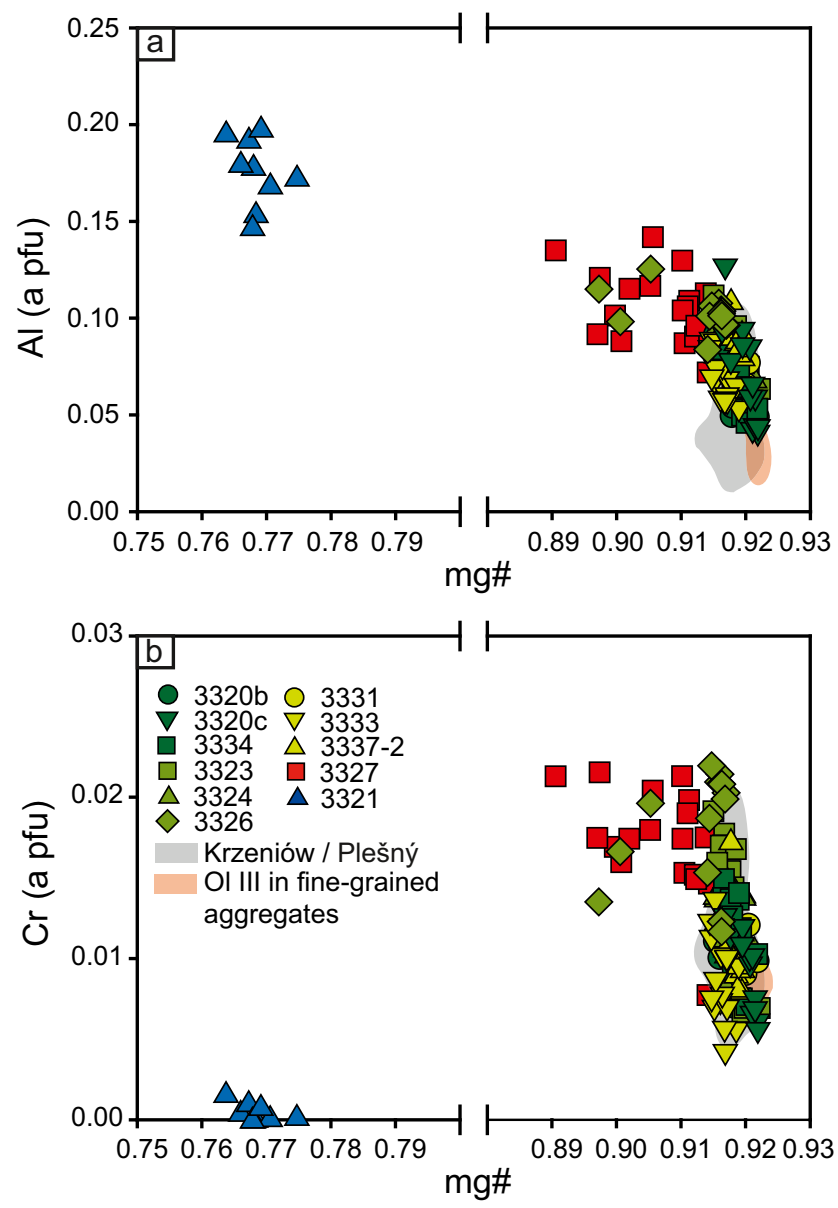

Fig. 6 Relationships between mg\# and $\mathrm{Al}$ (a) and $\mathrm{Cr}$ (b) in orthopyroxene. The field of orthopyroxene from the Krzeniów A xenoliths after Matusiak-Małek et al. (2014), that of olivine from Plešný after Ackerman et al. (2015) 

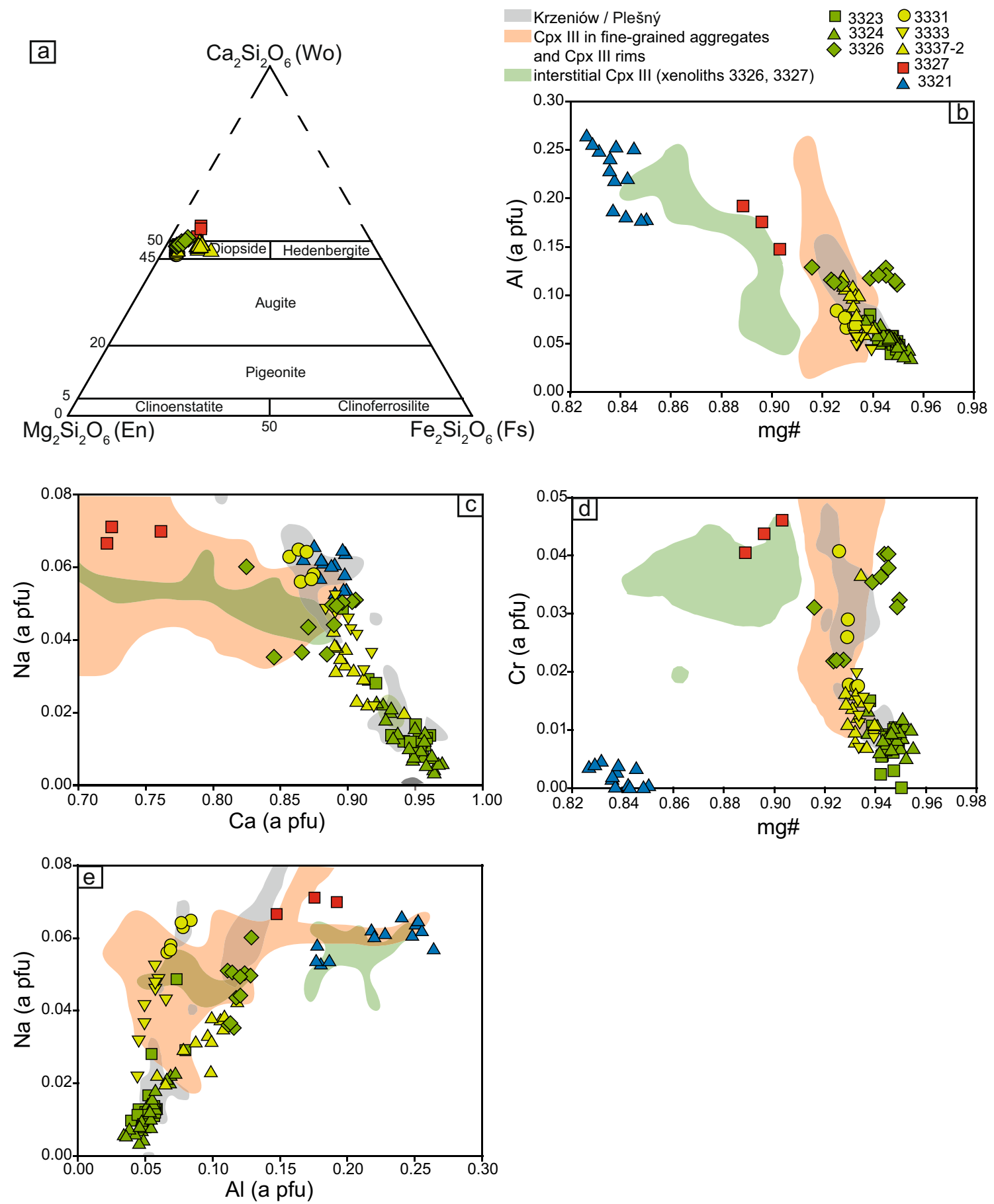

Fig. 7 Composition of clinopyroxene from Steinberg xenoliths. The field of clinopyroxene from the Krzeniów A xenoliths after MatusiakMałek et al. (2014), that of olivine from Plešný after Ackerman et al. (2015). (a) Points representing clinopyroxene in the $\mathrm{Mg}_{2} \mathrm{Si}_{2} \mathrm{O}_{6}$ -

lamellae in clinopyroxene I have cr\#=0.33-0.41 and $\mathrm{mg \# =}$ 0.69-0.74 (Appendix Table 5).

The clinopyroxene (mg\# 0.95, Al 0.11 a pfu, Ca $0.90-0.91$ a pfu) - spinel $(\mathrm{mg} \#=0.62-0.67, \mathrm{cr} \#=0.47-0.51)$ cluster in harzburgite 3326 contains spongy clinopyroxene III (mg\# $0.88-0.91, \mathrm{Al} 0.16-0.24$ a pfu and $\mathrm{Ca} 0.78-0.88$ a pfu).
$\mathrm{Fe}_{2} \mathrm{Si}_{2} \mathrm{O}_{6}-\mathrm{Ca}_{2} \mathrm{Si}_{2} \mathrm{O}_{6}$ diagram. (b) Relationships between mg\# and $\mathrm{Al}$ content. (c) Relationships between $\mathrm{Ca}$ and $\mathrm{Na}$ content. (d) Relationship between $\mathrm{mg} \#$ and $\mathrm{Cr}$ content. (e) Relationship between $\mathrm{Al}$ and $\mathrm{Na}$ content

Olivine III in this aggregate contains $88.8-89.2 \%$ Fo and $0.24-0.27$ wt. $\% \mathrm{NiO}$. Orthopyroxene III is characterized by $\mathrm{mg} \#=0.90$ and $\mathrm{Al}$ content from 0.11 to $0.13 \mathrm{a}$ pfu. Interstitial, locally spongy clinopyroxene III (mg\# 0.84-0.91, Al 0.070.24 a pfu, Ca $0.79-0.88$ a pfu, Appendix Table 4) also occurs in harzburgite 3326. Amoeboid remnants of orthopyroxene in 


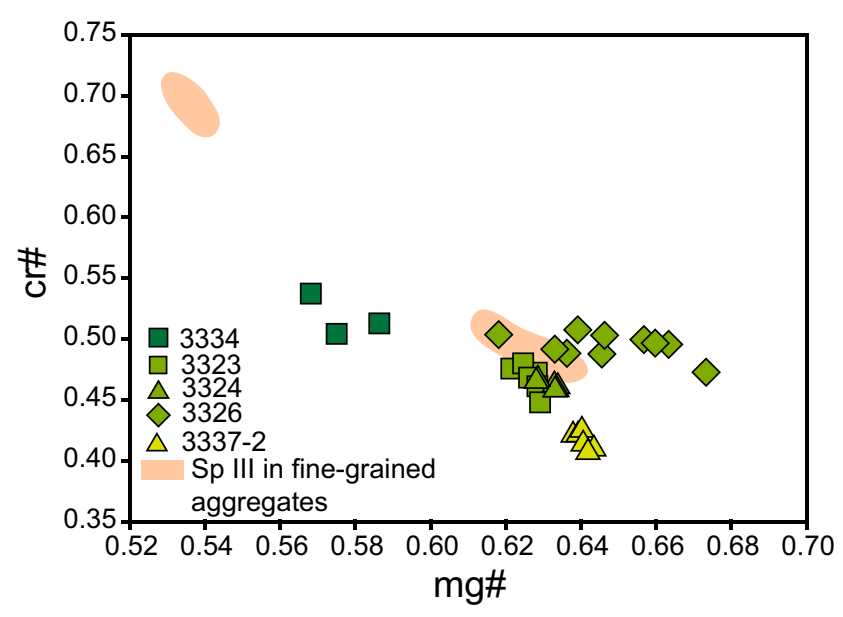

Fig. 8 Diagram of mg\# vs. cr\# showing composition of spinel from Steinberg xenoliths

interstitial clinopyroxene have $\mathrm{mg} \#=0.89-0.90$, contain $\mathrm{Al}$ between 0.08 and 0.13 a pfu and $\mathrm{Cr} 0.02$ a pfu.

\section{Mineral major and trace element composition - dunite B}

Dunite 3327 contains olivine with forsterite content ranging from 87.6 to $91.2 \%$ (Fig. 5a). Variation of forsterite content in olivine I is random. The Ca content is $<800 \mathrm{ppm}$. A few grains have the form of olivine I, but contain $>800 \mathrm{ppm} \mathrm{Ca}$; they contain 86.5 $88.2 \%$ Fo (Fig. 5b, Appendix Table 3). The marginal parts of olivine I grains contain up to $1500 \mathrm{ppm} \mathrm{Ca}$. Orthopyroxene I has mg\# 0.89-0.91 and contains $0.07-0.14$ a pfu of $\mathrm{Al}$ (Fig. 6a, Appendix Table 4). It is characterized by HREE contents below primitive mantle level. It is heterogeneous in terms of LREE whose content vary from 0.01 to $1 \times \mathrm{PM}\left(\mathrm{La}_{\mathrm{N}} / \mathrm{Lu}_{\mathrm{N}}=0.1-4.1\right.$; Fig. 9e, Appendix Table 6). Orthopyroxene I in dunite shows negative Ta and positive Ti anomalies (Fig. 9f). Clinopyroxene I is characterized by mg\# $0.89-0.90$, and contains $0.15-0.19$ and 0.72-0.76 a pfu of Al and Ca, respectively (Fig. 7b, c, Appendix Table 4). The grains of clinopyroxene I were too small to allow reliable LA ICPMS analyses of trace elements.

Interstitial, perforated clinopyroxene III (mg\# 0.85-0.91, Al 0.05-0.22 a pfu, Ca 0.68-0.86 a pfu, Appendix Table 4) contains embedded oval olivine III grains $(83.5-88.2 \%$ Fo and $0.24-0.36$ wt. $\%$ of $\mathrm{NiO}$ and $\mathrm{Ca}>1000 \mathrm{ppm})$. Spinel III in interstitial clinopyroxene III is characterized by $\mathrm{mg} \#=0.58$ and $\mathrm{cr} \#=0.48$. Interstitial, perforated clinopyroxene REE patterns are characterized by slight enrichment in LREE (Fig. 10c), clear $\mathrm{Zr}$-Hf negative anomalies and concentrations of $\mathrm{Rb}, \mathrm{Ba}$, Th, U below primitive mantle (Fig. 10d, Appendix Table 6)

\section{Mineral major and trace element composition - wehrlite C}

Olivine I in wehrlite 3321 contains $72.7-73.7 \%$ Fo and 0.05 0.11 wt. $\%$ of $\mathrm{NiO}$ (Fig. 5a, Appendix Table 3). Orthopyroxene I is characterized by correspondingly low mg\# $(0.76-0.77)$ and relatively high $\mathrm{Al}$ content $(0.15-0.20$ a pfu; Fig. 6a, Appendix Table 4). Clinopyroxene I is diopside with $\mathrm{mg \#}$ between 0.83 and 0.85 . Its $\mathrm{Al}$ content varies from 0.18 to 0.26 a pfu and Ca content is $0.88-0.90$ a pfu (Fig. 7b, c, Appendix Table 4). Symplectite S1 is composed of aluminous spinel (no Cr, mg\# 0.60-0.61, Appendix Table 5) and clinopyroxene which has mg\# $0.83-0.85$ and contains 0.18 0.22 a pfu of $\mathrm{Al}$ and $0.89-0.90$ a pfu of $\mathrm{Ca}$ (Appendix Table 4). Symplectites S2 consist of olivine of 75.0-76.1\% Fo and 0.02-0.05 wt \% of NiO (Appendix Table 3), orthopyroxene (mg\# $=0.77, \mathrm{Al}=0.15-0.16$ a pfu, Appendix Table 4), spinel (mg\# 0.66-0.67, no Cr, Appendix Table 5) and alkali feldspar $\left(\mathrm{Or}_{31-42} \mathrm{Ab}_{56-65} \mathrm{An}_{2-5}\right)$. Sulfide grains in xenolith 3321 are heterogeneous with many exsolution features. They have composition of pyrrhotite with pentlandite flame-like lamellae. Some of sulfide grains have monosulfide solid solutions (MSS) composition with rim enriched in copper (Appendix Table 7).

The REE pattern of orthopyroxene I is characterized by a decrease of PM-normalized concentrations from $\mathrm{Lu}$ to $\mathrm{La}$ (Fig. 9g; $\mathrm{La}_{\mathrm{N}} / \mathrm{Lu}_{\mathrm{N}}=0.02, \mathrm{La}_{\mathrm{N}} / \mathrm{Sm}_{\mathrm{N}}=0.4$, Appendix Table 6). The trace element pattern shows depletion relative to primitive mantle and positive Hf, Zr, Ti anomalies (Fig. 9h). The REE pattern of clinopyroxene I is slightly LREE-depleted (Fig. 10e; $\mathrm{La}_{\mathrm{N}} / \mathrm{Lu}_{\mathrm{N}}=0.3-0.5$, Appendix Table 6). Multiple analyses show almost constant contents of $\mathrm{Eu}(0.5-0.7 \mathrm{ppm})$ and $\mathrm{La}(0.4$ 0.5 ppm, Fig. 10f), but part of the REE patterns show slight positive Eu anomaly (Eu/Eu*=1.1-2.1; Fig. 10e). This results from decreasing contents of another elements (Fig. 10e). The flat LREE-depleted patterns without Eu anomaly occur in large grains which are not in direct contacts with $\mathrm{S} 1$ symplectite. The slight $\mathrm{Eu}$ anomaly occurs in grains in contact with $\mathrm{S} 1$ symplectite, whereas the most pronounced one appears in clinopyroxene forming that symplectite. The positive Eu anomaly is connected with a positive $\mathrm{Sr}$ anomaly, whereas the grains with no/weak positive anomaly exhibit no or negative $\mathrm{Sr}$ anomaly in their trace element patterns (Fig. 10f).

\section{Phases forming the fine-grained aggregates and clinopyroxene III rims on orthopyroxene and its origin}

Olivine III occurs in all studied intergranular aggregates (Appendix Table 2). Its forsterite content is similar to that of olivine I (Fig. 5a), but it contains significantly more $\mathrm{Ca}(960$ 2600 ppm), while $\mathrm{NiO}$ content is slightly decreased (Fig. 5, Appendix Table 3). Composition of some parts of clinopyroxene III overlaps partly with that of clinopyroxene I. However, the trend defined by clinopyroxene III in the mg\# vs. Al diagram (Fig. 7b, Appendix Table 4) is different than that of clinopyroxene $\mathrm{I}$, and the content of $\mathrm{Cr}$ is usually higher (Fig. 7d). Orthopyroxene III is extremely scarce (xenolith 

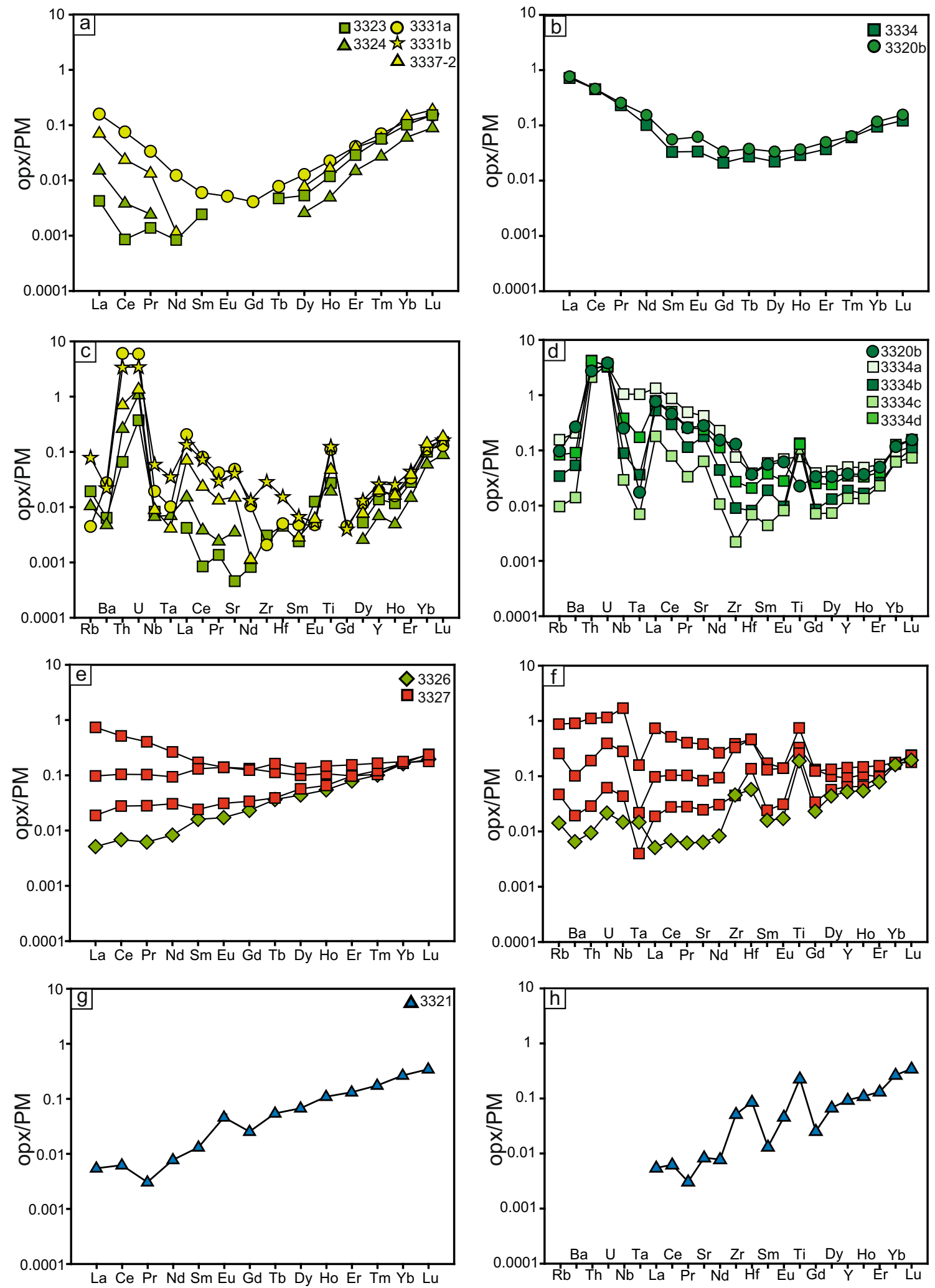

Fig. 9 Primitive mantle-normalized (McDonough and Sun 1995) REE $(\mathbf{a}, \mathbf{b})$ and trace elements $(\mathbf{c}, \mathbf{d})$ patterns of orthopyroxene I from xenoliths 3320 b, 3323, 3324, 3331, 3334 and 3337-2; orthopyroxene I REE (e) and trace elements (f) patterns from harzburgite 3326 and dunite 3327;

orthopyroxene I REE (g) and trace elements (h) patterns from wehrlite 3321; because of variation in trace element contents in orthopyroxene from harzburgite 3334,4 patterns (a, b, c and $\mathbf{d})$ are shown 

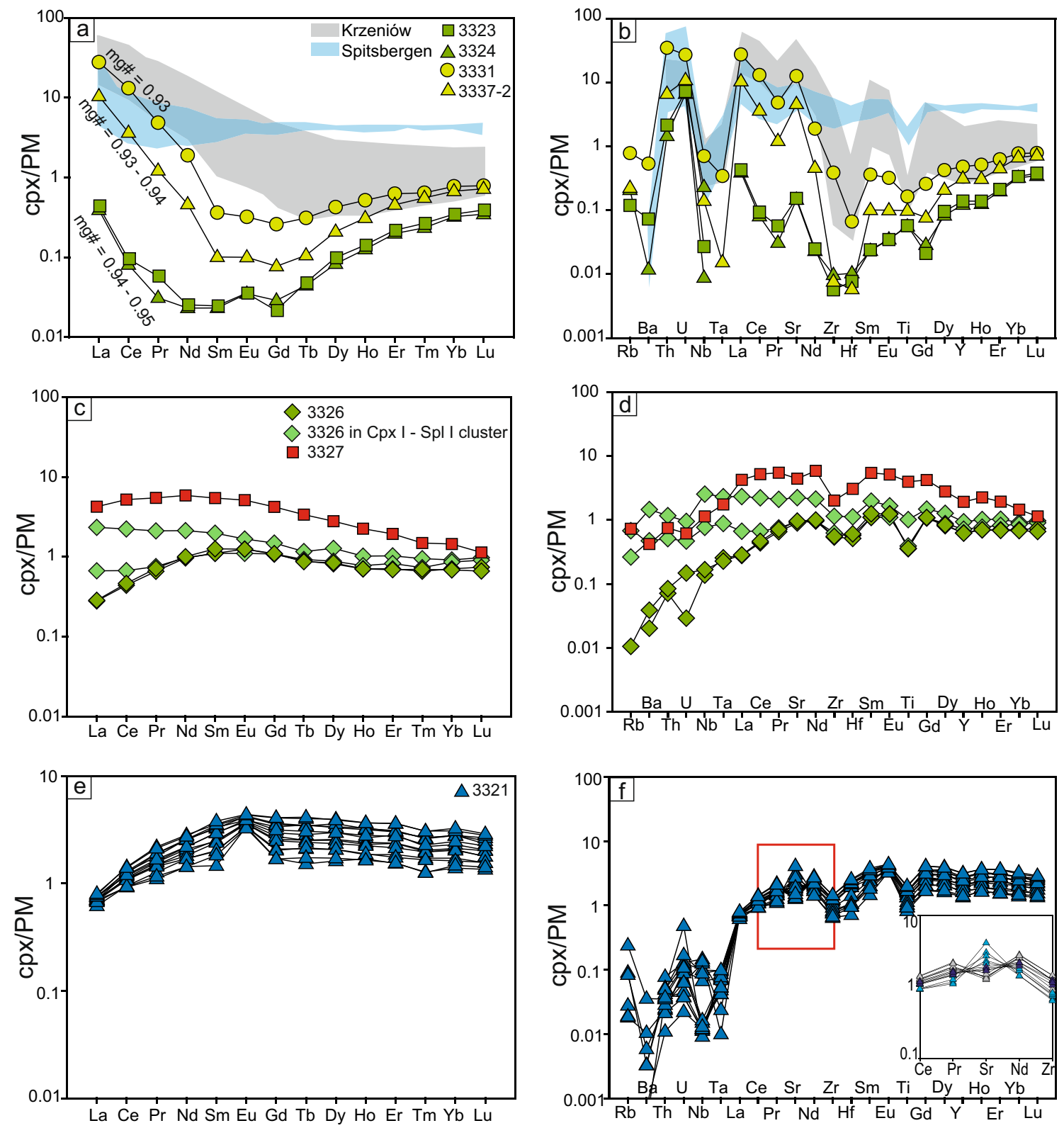

Fig. 10 Primitive mantle (McDonough and Sun 1995) normalized REE and trace elements patterns of clinopyroxene. (a), (b) Clinopyroxene I from xenoliths 3323, 3324, 3331 and 3337-2; (c), (d) Clinopyroxene I

3334 only) and forms cores of clinopyroxene III. Its chemical composition is identical to that of orthopyroxene I and we suggest it represents fragments of orthopyroxene I not fully reacted with an alkaline melt (Shaw 1999). Spinel III has partly highly chromian compositions. In some fine-grained aggregates, the chemical composition of spinel III is similar to that of spinel I (Fig. 8, Appendix Table 5). Alkali feldspar, occurring commonly in the aggregates, has strongly variable composition (Appendix Table 2). Glass has a composition similar to trachybasalt.

Clinopyroxene III forming rims on orthopyroxene I has a variable composition (Appendix Table 4). Clinopyroxene III from xenolith 3326 and interstitial clinopyroxene III from xenolith 3327; (e), (f) Clinopyroxene from wehrlite 3321

rims associated with fine-grained aggregates are characterized by $\mathrm{mg}$ \# between 0.92 and $0.94, \mathrm{Al}$ content between 0.02 and 0.12 a pfu (Fig. 7b), and Ca from 0.67 to 0.94 a pfu (Fig. 7c). Interstitial clinopyroxene III rims have mg\# between 0.91 and $0.93, \mathrm{Al}$ content is $0.04-0.05 \mathrm{a}$ pfu (in extreme cases up to 0.20; Fig. 7b) and $\mathrm{Ca}=0.75-0.92$ a pfu (Fig. 7c).

A fine-grained aggregate in xenolith 3321 consists of olivine III (75.5 \% Fo, NiO=0.07 wt. \%, Appendix Table 3) and clinopyroxene III. The latter forms elongated rims on olivine I surrounding the fine-grained aggregates $(\mathrm{mg} \#=0.83-0.84$, $\mathrm{Al}=0.20-0.22 \mathrm{a} \mathrm{pfu}, \mathrm{Ca} 0.85-0.90 \mathrm{a}$ pfu) or poikilitic grains (mg\# 0.78-0.84, Al 0.08-0.13 a pfu, Ca 0.89 a pfu, Appendix 
Table 4). Aggregates from wehrlite 3321 contain crystals of alkali feldspar $\left(\mathrm{Or}_{30-43} \mathrm{Ab}_{54-63} \mathrm{An}_{3-8}\right)$ and subhedral crystals of normally zoned plagioclase $\left(\mathrm{Or}_{1} \mathrm{Ab}_{24-26} \mathrm{An}_{73-75}\right.$ in cores to $\mathrm{Or}_{3-22} \mathrm{Ab}_{48-69} \mathrm{An}_{9-49}$ in rims).

The origin of intergranular, fine-grained aggregates may be related to: (1) melting of hydrous phases (Shaw 2009); (2) infiltration of metasomatic melts at mantle depths (O’Connor et al. 1996; Shaw and Klügel 2002) or (3) infiltration of host magma during xenolith uplift (Shaw and Dingwell 2008). In Steinberg xenoliths, similarly to xenoliths from other nearby outcrops of volcanic rocks (Plešný, Ackerman et al. 2015; Księginki, Puziewicz et al. 2011, Fig. 1), no hydrous phases were found. Moreover, no phases formed during amphibole breakdown (e.g., rhönite) occur in the xenoliths, therefore we consider the formation of aggregates by amphibole breakdown/melting as unlikely. Presence of subhedral, anorthite-rich plagioclase in some aggregates in xenolith 3321 points to its formation by host basanite infiltration, but no direct connection between any of the aggregate and host rock was found.

Composition of olivine III, clinopyroxene III and spinel III from the glass-bearing aggregates overlaps partly with composition of coexisting olivine I, clinopyroxene I and spinel I, respectively. This suggests that the aggregates are formed of primary phases which partly reacted with a percolating/ infiltrating medium. This reaction caused elevation of $\mathrm{Ca}$ and impoverishment in $\mathrm{NiO}$ contents in olivine, as well as $\mathrm{Al}, \mathrm{Na}$ and $\mathrm{Ca}$ enrichment in clinopyroxene III (Figs. 5 and 7). The $\mathrm{Al}$ and $\mathrm{Na}$ enrichment can be explained by reaction with a Si-undersaturated melt, but this reaction would cause only minor increase in Ca content (Tursack and Liang 2012). Significant increase in Ca content in Steinberg xenoliths may however point to reaction under high pressure conditions (Brey et al. 1990). Orthopyroxene is dissolved during reaction with alkaline silicate melt and secondary clinopyroxene is formed (Shaw 1999) as vermicular rims of clinopyroxene III on orthopyroxene I.

Therefore, we suggest that the fine-grained aggregates result from reaction between peridotite and alkaline silicate melt at high pressures. Presence of primary peridotite phases in the aggregates as well as their fine-grained textures show that the process was interrupted and frozen by entrainment of fragments of infiltrated rock into the erupting basanite host.

\section{Temperatures of equilibration}

The commonly used orthopyroxene-clinopyroxene solvus geothermometer of Brey and Köhler (1990), when applied to coexisting grains of ortho- and clinopyroxene I in group A harzburgites, yields results which vary for over $110{ }^{\circ} \mathrm{C}$ in the scale of a thin-section, demonstrating that the phases are not in equilibrium in terms of major elements. The same result was found for the Al- in orthopyroxene thermometer of WittEickschen and Seck (1991), applicable in samples containing spinel of appropriate composition. In our opinion this shows that spinel, which defines saturation of $\mathrm{Al}$ in the system, was not equilibrated with orthopyroxene.

Another thermometer that was used to estimate temperatures was based on REE contents in ortho- and clinopyroxene (Liang et al. 2013). Temperature varies from $836 \pm 12{ }^{\circ} \mathrm{C}$ (harzburgite 3331), 866 $\pm 12{ }^{\circ} \mathrm{C}$ (harzburgite 3324), $911 \pm$ $28{ }^{\circ} \mathrm{C}$ (harzburgite $3337-2$ ), up to $979 \pm 19{ }^{\circ} \mathrm{C}$ (harzburgite 3323). In harzburgite 3326 result was $965^{\circ} \mathrm{C}$ with very high error (up to $104^{\circ} \mathrm{C}$ ) and thus not correct (Liang et al. 2013).

\section{Discussion}

\section{Evolution of group A harzburgites}

The group A harzburgites 3320b, 3320c and 3334 from Steinberg do not contain clinopyroxene. In these xenoliths orthopyroxene is Al-poor (0.04-0.09 a pfu). Its composition corresponds to the ca. 20-31.5\% degree of melting of primitive mantle, as calculated by Upton et al. (2011, see Fig. 11a). Such characteristics corresponds to the A0 harzburgites from Krzeniów basanite (Matusiak Małek et al. 2014), which have been interpreted as residues after extreme depletion.

Clinopyroxene-bearing harzburgites 3323, 3324, 3331, $3333,3337-2$ are characterized by orthopyroxene containing $0.05-0.12$ atoms of $\mathrm{Al}$ pfu and $0.01-0.06$ atoms of $\mathrm{Ca}$ pfu. Clinopyroxene I is Al-poor (0.03-0.13 a pfu), and reaches extremely high mg\# (up to 0.96). The chemical composition of this clinopyroxene plots away from the melting trend in the $\mathrm{MgO}-\mathrm{Al}_{2} \mathrm{O}_{3}$ diagram of Upton et al. (2011, see Fig. 11b), suggesting that the clinopyroxene was added to the rock after the melting event which depleted orthopyroxene in Al. Indeed, the Fe-Mg partitioning between the two phases is not the equilibrium one as is shown by our thermometric calculations. Therefore, we propose that the clinopyroxene in these harzburgites is a "stealth"/modal metasomatic phase (O'Reilly and Griffin 2013) which was added to the rock shortly before its entrainment in the erupting host magma. Thus, the degree of partial melting cannot be estimated on the basis of trace element composition of clinopyroxene, although its $\mathrm{Yb}_{\mathrm{N}} / \mathrm{La}_{\mathrm{N}}$ ratio follows the fractional melting trend in spinel stability field defined by Norman (1998). The extremely low HREE contents in most of clinopyroxene I would require extremer (impossible to model) melting in the garnet stability field (Hellebrand et al. 2002) and may reflect the formation of the clinopyroxene after the HREE-poor orthopyroxene (Peslier et al. 2002; Ionov et al. 2005).

Clinopyroxene REE patterns of harzburgites 3323, 3324, 3331 and 3337-2 are U-shaped, enriched in LREE relative to MREE. Enrichment in LREE results from metasomatic input 

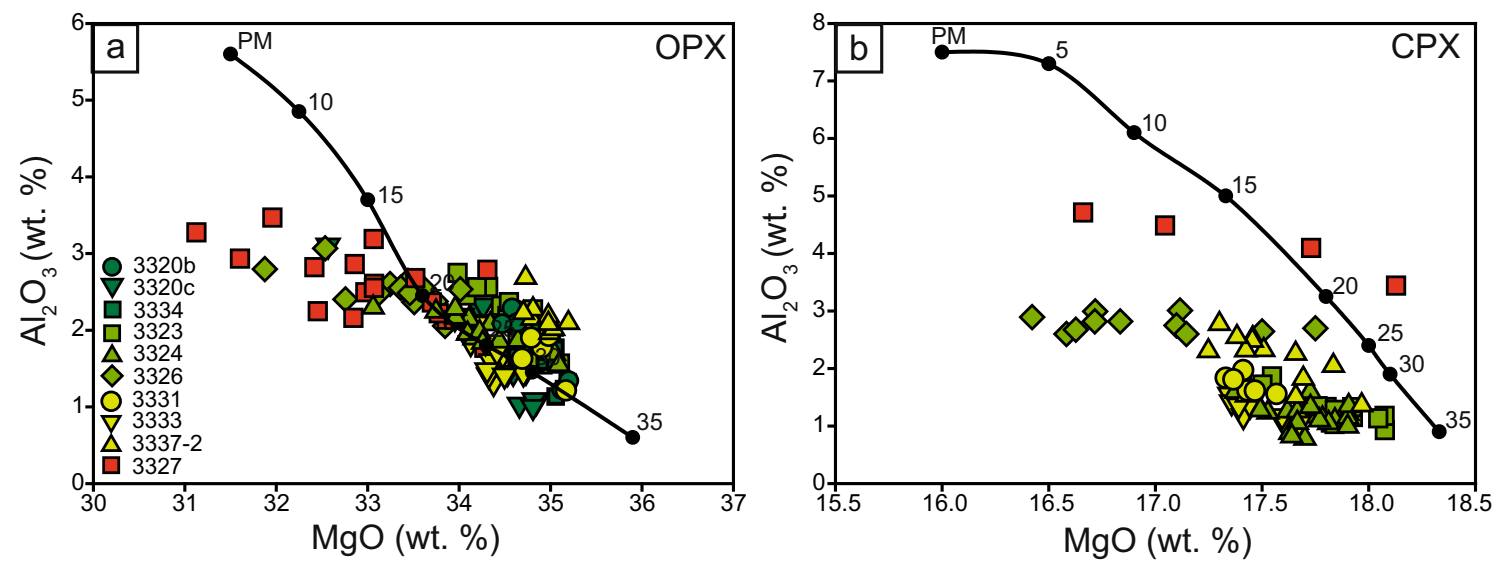

Fig. $11 \mathrm{MgO}$ versus $\mathrm{Al}_{2} \mathrm{O}_{3}$ diagrams for a) orthopyroxene and b) clinopyroxene. Evolution of content of $\mathrm{MgO}$ and $\mathrm{Al}_{2} \mathrm{O}_{3}$ in ortho- and clinopyroxene during melting of primitive mantle (fertile lherzolite) according to Upton et al. (2011)

of the most incompatible elements (e.g., Frey and Green 1974; Norman 2001). Group A clinopyroxene is in fact similar to the Krzeniów A1 clinopyroxene (cf. Fig. 10a and see Matusiak Małek et al. 2014), although it is more depleted relative to primitive mantle. The $\mathrm{La}_{N} / \mathrm{Lu}_{\mathrm{N}}$ ratios change gradually from 1.1 (harzburgite 3324) to 35.3 (harzburgite 3331) and are negatively correlated with mg-number in clinopyroxene (Fig. 10a). We interpret this as a result of chromatographic metasomatism (Ionov et al. 2002, 2006), in which the LREE-rich metasomatic agent migrates away from the source (vein?) and reacts with the host peridotite to produce clinopyroxene. The latter becomes increasingly depleted in LREE away from the source and we assume that harzburgite 3331 could have been located nearest to the source, whereas harzburgite 3324 may have been the farthest. The chromatographic effect is visible also in increasing depths of $\mathrm{Nb}$-Ta and $\mathrm{Zr}-\mathrm{Hf}$ negative and $\mathrm{Sr}$ positive anomalies (Fig. 10b). These anomalies, as well as the Th-U ones, are deep (Fig. 10b), which, together with high mg\# and low Al content, suggests that the most likely metasomatising agent was carbonatitic melt (Yaxley et al. 1991; Rudnick et al. 1993; Ionov et al. 1993 and Coltorti et al. 1999). If this is the case, a strong negative $\mathrm{Ti}$ anomaly should occur in clinopyroxene, but the $\mathrm{Ti} / \mathrm{Ti}^{*}$ is only $0.6-2.3$. We explain this by very low content of elements neighbouring Ti in the diagram, which results in the lack of Ti anomaly. The "carbonatitic" effects increase in the assumed direction away from the source of the metasomatising agent. By analogy to the Krzeniów (Matusiak Małek et al. 2014) and Spitsbergen (Ionov et al. 2002) chromatographic systems, we suggest that this agent might have been carbonatite-rich silicate melt (Fig. 10a, b). In Krzeniów xenoliths the carbonatite component was unmixed in distal parts of chromatographic section after the miscibility limit was exceeded due to exhaustion of the silicate component. Similar mechanism of melts separation was described by Ionov et al. (2006) in xenoliths from Tok, Siberia. Since the major- and trace elements relationships in clinopyroxene are similar in Steinberg, we suggest that it originated here in a similar way. The deep $\mathrm{Zr}$-Hf negative anomalies are rather rare and seem to be characteristic of the Lower Silesian - Upper Lusatian domain of European lithospheric mantle (Downes et al. 2015)

The occurrence of "A" harzburgites in both Krzeniów (offrift location) and Steinberg (on-rift) shows that the lithospheric mantle beneath the Eger Rift contains peridotites relatively little affected by pre-eruptive alkaline silicate melt metasomatism. Thus, the lithospheric mantle beneath the Eger Rift is possibly a mosaic of lithologies affected to different degrees by Cenozoic pre-eruptive metasomatism. Locally the pre-eruptive metasomatic effects are very extensive and the record of earlier events in peridotites is obliterated, as was shown in Księginki (Puziewicz et al. 2011) located several kilometres of Steinberg.

\section{Peridotite-melt reactions: origin of "B" dunite}

The dunite 3327 was classified as belonging to group " $\mathrm{B}$ ", as its olivine I is enriched in Fe compared to group A. This imply either a cumulate origin (Rehfeldt et al. 2007) for this rock or formation by reaction between percolating silicate melt and peridotite (Kelemen et al. 1990). Dunite 3327 shows no cumulative texture and its olivine I is characterized by strongly heterogeneous forsterite content ( 86.5 to $90 \%$ Fo). The lower values occur always in outer parts of grains, while core compositions of some crystals are rich in forsterite and resemble values characteristic for group A xenoliths (Fig. 5a). Such a feature is widely explained a result of reaction with alkaline melt (e.g., Kelemen et al. 1990; Ionov et al. 2005; Tursack and Liang 2012 and references therein). Therefore we suggest that dunite 3327 has a reactive origin.

Vermicular, thick rims of clinopyroxene III enveloping orthopyroxene I (Fig. 3f) are characteristic for this xenolith and occur commonly in mantle xenoliths from SW Poland (e.g., Matusiak-Małek et al. 2010; 2014). Shaw (1999) attributed their formation to dissolution of orthopyroxene I by 
reaction with silica-poor alkaline melt. In most Steinberg xenoliths the rims are rather narrow, but in dunite 3327 they reach up to $100 \mu \mathrm{m}$, suggesting longer reaction time and/or better supply of alkaline melt to the reaction site. Amoeboid, locally minute remnants of orthopyroxene I embedded in spongy clinopyroxene III show that complete dissolution of orthopyroxene I was possible. This is further evidence for the reactive origin of the dunite.

The dunite 3327 contains interstitial, sieved clinopyroxene enclosing oval grains of olivine III. Composition of oval olivine III is characterized by low Fo and high Ca contents and resembles that of marginal parts of olivine I in contact with interstitial clinopyroxene III. This suggests that the oval olivine III represents resorbed fragments of olivine I. Fragmentation of olivine I as well as formation of perforated clinopyroxene was probably due to infiltration of a melt. The infiltrating melt reacted with the host orthopyroxene producing secondary, perforated clinopyroxene. Remnants of the unreacted orthopyroxene are still present as the amoeboid crystals. The perforated clinopyroxene in dunite 3327 has higher mg\# and is depleted in Ca relative to those of " $\mathrm{A}$ " harzburgites.

Interstitial, perforated clinopyroxene from 3327 shows a flattened, slightly LREE-enriched pattern with negative inflection at the most incompatible elements. Such a REE pattern is characteristic for clinopyroxene reacting with alkaline silicate melt. We have calculated a trace element composition of a melt in equilibrium with 3327 clinopyroxene (Fig. 12), using partition coefficients of Hart and Dunn (1993). The only significant differences between the calculated melt and host basanite are the higher contents of $\mathrm{Nb}, \mathrm{Ta}$ and $\mathrm{Ba}$ in the theoretical melt. Since these elements are most affected by analytical uncertainties during LA-ICP-MS analyses and data reduction, the observed difference can be an artefact. We thus infer that the interstitial clinopyroxene in dunite 3327 results from reaction of a peridotite with alkaline-silicate melt of composition very close to the host basanite. The interstitial occurrence of clinopyroxene III suggests that the rock is

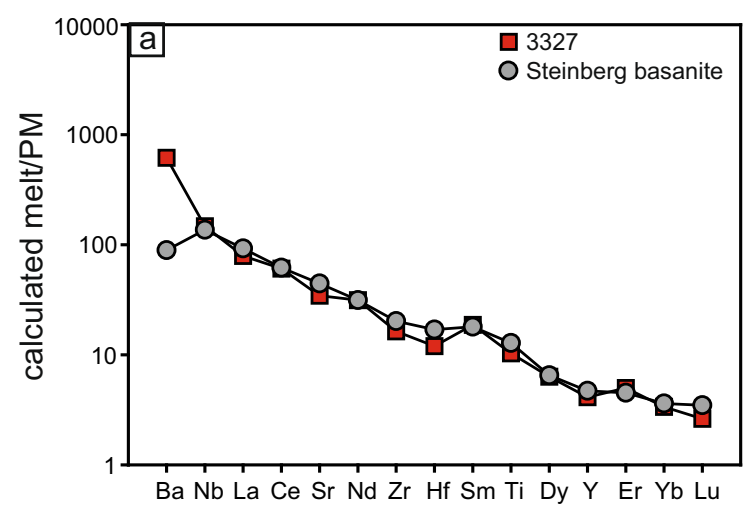

Fig. 12 The calculated trace element composition of silicate melt in equilibrium with (a) clinopyroxene from dunite 3327 compared to the Steinberg basanite and (b) clinopyroxene from harzburgite 3326 and texturally unequilibrated, which implies that melt percolation which caused the metasomatism occurred shortly before entrainment of this mantle piece within the erupting lava.

\section{The " $C$ " wehrlite 3321 and " $A$ " harzburgite 3326 - frozen} metasomatic melt and results of its action?

The wehrlite 3321 consists of minerals whose chemical composition (olivine Fo $72.7-73.7$, clinopyroxene $\mathrm{mg} \# 0.83-0.85$, $\mathrm{Al} 0.18-0.26$ a pfu, orthopyroxene mg\# $0.76-0.77$ and $\mathrm{Al}$ $0.15-0.20$ a pfu) suggests a non-mantle origin (e.g., Arai 1994; Griffin et al. 1999). Such a composition classifies this xenolith into group 2 of Frey and Prinz (1978) and plot outside the Olivine-Spinel Mantle Array by Arai (1994). Frey and Prinz (1978) suggested a cumulative origin for this group, but it is possible to form them also by melt-rock reaction (see discussion about xenolith 3327). This rock contains numerous grains of sulfides which is uncommon in mantle xenoliths from Bohemian Massif (Kochergina personal information, Bukała et al. 2015). On the other hand, sulfides are common in basaltic cumulates. Moreover, the mg-numbers of the silicates are $<0.85$ and the composition of spinel is almost chromium-free. Therefore we suggest that wehrlite is a cumulative rock. Lack of visible cumulative texture is easily explained by recrystallization, which also produced the spinelclinopyroxene symplectites (Fig. 3e).

Symplectites occur abundantly in mantle rocks and are interpreted as a product of decompression-triggered breakdown of a mineral phase, usually garnet (Shimizu et al. 2008 and references therein). Reconstruction of the composition of the primary phase is possible if modal and chemical composition of the symplectite-forming phases are combined. The spinel-clinopyroxene symplectites $\mathrm{S} 1$, when reintegrated into a homogeneous phase, have approximate composition $\mathrm{SiO}_{2}$ 38.07, $\mathrm{TiO}_{2}$ 0.10, $\mathrm{Al}_{2} \mathrm{O}_{3} 20.70, \mathrm{Cr}_{2} \mathrm{O}_{3}$ 0.01, $\mathrm{FeO} 8.92, \mathrm{MnO}$ 0.14, $\mathrm{NiO} 0.04, \mathrm{MgO} 15.48, \mathrm{ZnO} 0.07, \mathrm{CaO} 16.62, \mathrm{Na}_{2} \mathrm{O}$ $0.54, \mathrm{~K}_{2} \mathrm{O} 0.01$, sum 100.69 wt. \% (28.02 vol. \% of spinel

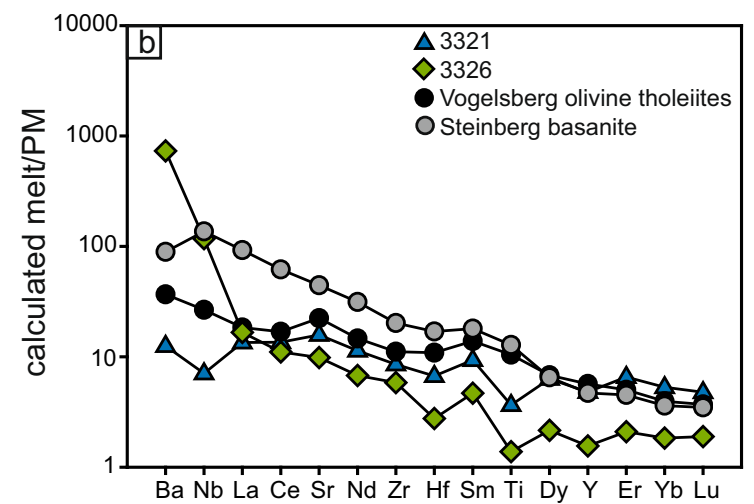

wehrlite 3321 compared to the Vogelsberg olivine tholeiites (average value; Bogaard and Wörner 2003, see text for details). Partition coefficients of Hart and Dunn (1993) 
[averaged analyses of spinel from symplectite S1] and 71.98 vol. \% of clinopyroxene spinel [averaged analyses of clinopyroxene from symplectite S1]). This composition is far from the typical peridotitic garnet one, as it corresponds approximately to $\mathrm{Fe}_{0.6} \mathrm{Mg}_{1.7} \mathrm{Ca}_{1.3} \mathrm{Al}_{1.8} \mathrm{Si}_{2.8} \mathrm{O}_{12}$. The relatively low $\mathrm{Mg}$ and very high $\mathrm{Ca}$ content make it crudely similar to garnets occurring in high-pressure cumulates from hydrous tholeiitic/andesitic magmas occurring in the roots of volcanic arcs (e. g., Ringuette et al. 1999; Müntener et al. 2001). Textural relationships suggest that the olivineorthopyroxene-spinel-alkali feldspar symplectites S2 originated by replacement of the $\mathrm{S} 1$ by fine-grained aggregates.

The REE patterns of clinopyroxene in wehrlite 3321 are either (1) LREE-depleted, flat at MREE, or (2) LREEdepleted with positive Eu anomaly. Those which are flat occur in clinopyroxene grains not related to S1 clinopyroxene-spinel symplectite, whereas those with Eu anomaly occur in clinopyroxene forming the S1 symplectite or in contact with it. Thus, we interpret the flat MREE patterns (1) to be the primary ones, and those with Eu anomaly (2) to be related to the symplectite formation. The type (1)" MREE flat" patterns of clinopyroxene from 3321 wehrlite could not have originated by crystal settling from the host LREE-enriched basanitic magma. This is shown by calculation of hypothetical trace element melt composition in equilibrium with 3321 clinopyroxene (partition coefficients of Hart and Dunn 1993). The calculated melt is impoverished in trace elements relative to the host basanite from Ba to Sm (Fig. 12). Thus, the 3321 wehrlite probably originated during an igneous event preceding the volcanic episode which brought it to the surface.

The only locality from Bohemian Massif where cumulative rocks containing LREE-depleted clinopyroxene have been described is Dobkovičky (Czech Republic, Ackerman et al. 2012), where it has been interpreted as the result of percolation of MORB-like melts in the lithospheric mantle. Sample 3321 is similar in nature, and we speculate that it could have originated by crystal settling from the magma of continental tholeiite affinity. The hypothetical trace element melt composition in equilibrium with 3321 clinopyroxene is similar to that of olivine tholeiites from Vogelsberg in Germany (Central part of the CEVP) which is the closest occurrence of continental tholeiites (Fig. 12; the pattern of Vogelsberg tholeiite is based on averaged analyses vb96-27, vb96-41, vb97-105, vb97-109, vb97-114, 2544, 2546, 2547 given by Bogaard and Wörner (2003); their Table 1). The Vogelsberg tholeiites originated by mixing of melts from the European Asthenospheric Reservoir and those coming from depleted, partly lithospheric sources (Bogaard and Wörner 2003).

The type (2) clinopyroxene REE patterns show a positive Eu anomaly which is not due to enrichment of the mineral in europium, but due to depletion in other REEs. Their origin is related to formation of symplectitic clinopyroxene. Thus, the origin of this pattern is different from those with Eu-positive anomaly which occur seldom in clinopyroxene coexisting with plagioclase in mafic rocks subjected to metamorphic recrystallization (e. g., Seifert and Chadima 1989; Morishita et al. 2009).

Some of the REE and trace element patterns of clinopyroxene in harzburgite 3326 are similar to those from wehrlite 3321 (cf. Fig. 10). The major element composition of this harzburgite places it in the "A" group of peridotites, but it is characterised by occurrence of thick rims (up to $100 \mu \mathrm{m}$ ) of vermicular clinopyroxene III on the orthopyroxene I, similar to those described in dunite 3327 . This shows that the rock was infiltrated by alkaline silicate melt. However, the clinopyroxene grains occurring individually are depleted in LREE, $\mathrm{Rb}, \mathrm{Ba}, \mathrm{Th}, \mathrm{U}$ and Ta relative to those forming the clinopyroxene-spinel clusters (cf. Fig. 10c,d). The LREEdepleted patterns are similar to those occurring in the clinopyroxene from wehrlitic cumulate (cf. Fig. 10), suggesting that the singular clinopyroxene grains possibly record the action of tholeiitic melt similar to that from which wehrlite 3321 precipitated, whereas those occurring in clusters record alkaline melt action (shown by clinopyroxene III rims on orthopyroxene). As similar rock, but of lherzolite composition, was described by Ackerman et al. (2015) from Medvědický vrch in České Středohoři. These authors attributed the origin of clinopyroxene with slightly LREE-depleted patterns, almost identical to those occurring in harzburgite 3326, to the action of LREE-depleted asthenospheric melts.

The clinopyroxene with LREE-depleted patterns, similar to those from the harzburgite 3326 , occurs in some xenoliths from CEVP, and are interpreted to record partial melting which affected host peridotite, followed in some instances by metasomatic overprint (e.g., Massif Central - Zangana et al. 1997; Downes et al. 2003, Olot in Spain - Bianchini et al. 2007). However, the major element composition of 3326 clinopyroxene departs significantly from the melting trend (Fig. 11b) which in our opinion indicates its metasomatic origin. Therefore, we consider that clinopyroxene in harzburgite 3326 records the stage of metasomatism by tholeiitic melts, followed by pre-eruptive "standard" alkaline melt metasomatism. We speculate that the tholeiitic metasomatism was also related to the Cenozoic volcanism in the region.

\section{Regional geological considerations}

The Steinberg basanite is located within the NE extension of the Eger Rift. It is close to the Ksieginki nephelinite ( $25 \mathrm{~km}$ to the north-east; Puziewicz et al. 2011), which is also located within the Rift. The neighbouring off-Rift locations are Plešný (30 km to the west; Ackerman et al. 2015) and Krzeniów (75 km to the east; Matusiak Małek et al. 2014). The Krzeniów and Plešný xenolith suites are dominated by depleted spinel harzburgites, similar to those from Steinberg, all belonging to the "group A" of Matusiak-Małek et al. (2014). These harzburgites were affected by chromatographic alkaline silicate-carbonatite metasomatism (Ackerman et al. 2015; 
Matusiak Małek et al. 2014) and appear to be the dominant SCLM lithology in the region (Puziewicz et al. 2015). The Ksiegginki xenolith suite is affected mostly by extensive synvolcanic alkaline melt metasomatism (Puziewicz et al. 2011). Mantle peridotites which record another metasomatic history are subordinate in all localities. This shows that the SCLM beneath the NE termination of the Eger Rift and its surroundings in the Lower Silesia - Upper Lusatia is dominated by spinel harzburgites relatively little affected by syn-volcanic carbonate-bearing alkaline melt percolation, and that the SCLM strongly affected by this percolation occurs only locally.

\section{Conclusions}

The xenolith suite from Steinberg in Upper Lusatia is dominated by aluminium-poor and highly magnesian harzburgites, which appear to be the dominant lithology of the Lower Silesian - Upper Lusatian domain of European lithospheric mantle. They correspond to the "A" type harzburgites defined by Matusiak-Małek et al. (2014). The "A" harzburgites represent depleted mantle lithology which was only slightly affected by chromatographic carbonatite-silicate metasomatism, and which preserved much of its primary depletion-related features.

Two of the Steinberg xenoliths record percolation of tholeiitic basaltic melts. We speculate that these melts are genetically similar to the olivine tholeiites from Vogelsberg in central Germany, which are the result of Cenozoic mixing of melts from European Asthenospheric reservoir and those from depleted, partly lithospheric sources (Bogaard and Wörner 2003). Cenozoic tholeiites do not occur to the east of Vogelsberg, but nevertheless melts of tholeiitic composition possibly have locally percolated in the lithospheric mantle. Their percolation through peridotite lead to the "tholeiitic" melt metasomatism or formation of igneous cumulate rocks with tholeiitic geochemical characteristics. Therefore, the mantle xenoliths containing LREE-depleted "tholeiitic" clinopyroxene, which occur scarcely in the lavas of CEVP, can originate by (1) tholeiitic melt metasomatism or (2) partial melting of peridotitic protoliths in the ocean ridge settings.

\footnotetext{
Acknowledgments We are grateful to Dmitri Ionov and Lukaš Ackerman for their thoughtful reviews, which inspired significant improvement of the paper. The authors are indebted to Hilary Downes for help in language editing. We thank our MSc student Michał Dajek who prepared the map presented in Fig. 1. The data presented in this paper are one of the results of the project DEC-2011/03/B/ST10/06248 (2012-2015) of Polish National Centre for Scientific Research to MMM. Large part of analytical work was performed thanks to the joint 2010-2011 and 2013-2104 projects in the frame of Austrian-Polish scientific and cultural cooperation agreement (Institute of Geological Sciences University of Wrocław and
}

Department of Lithospheric Sciences, University of Vienna, WTZ project Nr. PL 11/2013) and the fellowship of Austrian Government to AK in 2013.

\section{Appendix}

Table 1 Whole rock analyses of Steinberg basanite

\begin{tabular}{|c|c|c|c|}
\hline & & $\begin{array}{l}\text { Basanite } \\
3326\end{array}$ & $\begin{array}{l}\text { Basanite } \\
3331\end{array}$ \\
\hline $\mathrm{SiO} 2$ & wt. \% & 42.18 & 42.25 \\
\hline $\mathrm{TiO} 2$ & wt. \% & 2.56 & 2.59 \\
\hline $\mathrm{Al} 2 \mathrm{O} 3$ & wt. \% & 12.19 & 12.26 \\
\hline $\mathrm{Cr} 2 \mathrm{O} 3$ & wt. $\%$ & 0.075 & 0.073 \\
\hline $\mathrm{Fe} 2 \mathrm{O} 3$ & wt. \% & 12.01 & 12.05 \\
\hline $\mathrm{MnO}$ & wt. \% & 0.18 & 0.18 \\
\hline $\mathrm{CaO}$ & wt. \% & 10.96 & 11.06 \\
\hline $\mathrm{MgO}$ & wt. \% & 13.00 & 12.79 \\
\hline $\mathrm{P} 2 \mathrm{O} 5$ & wt. \% & 0.59 & 0.59 \\
\hline $\mathrm{Na} 2 \mathrm{O}$ & wt. \% & 3.06 & 3.05 \\
\hline $\mathrm{K} 2 \mathrm{O}$ & wt. \% & 1.13 & 1.14 \\
\hline LOI & wt. \% & 1.5 & 1.4 \\
\hline Sum & wt. \% & 99.48 & 99.48 \\
\hline $\mathrm{Ni}$ & ppm & 339 & 324 \\
\hline $\mathrm{Sc}$ & ppm & 24 & 24 \\
\hline $\mathrm{Ba}$ & ppm & 589 & 589 \\
\hline Th & ppm & 7.0 & 6.9 \\
\hline $\mathrm{U}$ & ppm & 1.5 & 1.7 \\
\hline $\mathrm{Nb}$ & ppm & 89.2 & 90.4 \\
\hline $\mathrm{Ta}$ & ppm & 5.1 & 4.9 \\
\hline $\mathrm{La}$ & ppm & 59.0 & 60.8 \\
\hline $\mathrm{Ce}$ & ppm & 103.8 & 103.4 \\
\hline $\operatorname{Pr}$ & ppm & 10.75 & 10.56 \\
\hline $\mathrm{Pb}$ & ppm & 8.6 & 15.3 \\
\hline $\mathrm{Sr}$ & ppm & 894.5 & 873.3 \\
\hline $\mathrm{Nd}$ & ppm & 37.7 & 40.7 \\
\hline $\mathrm{Zr}$ & ppm & 211.9 & 212.8 \\
\hline $\mathrm{Hf}$ & ppm & 4.8 & 4.8 \\
\hline $\mathrm{Sm}$ & ppm & 7.44 & 7.17 \\
\hline $\mathrm{Eu}$ & ppm & 2.27 & 2.22 \\
\hline $\mathrm{Gd}$ & ppm & 6.26 & 6.27 \\
\hline $\mathrm{Tb}$ & ppm & 0.85 & 0.85 \\
\hline Dy & ppm & 4.32 & 4.45 \\
\hline $\mathrm{Y}$ & ppm & 20.7 & 19.7 \\
\hline Но & ppm & 0.73 & 0.73 \\
\hline $\mathrm{Er}$ & ppm & 1.86 & 2.09 \\
\hline $\mathrm{Tm}$ & ppm & 0.24 & 0.26 \\
\hline $\mathrm{Yb}$ & $\mathrm{ppm}$ & 1.52 & 1.66 \\
\hline $\mathrm{Lu}$ & ppm & 0.23 & 0.24 \\
\hline$\Sigma$ REE & ppm & 236.97 & 242.68 \\
\hline $\mathrm{LaN} / \mathrm{LuN}$ & & 26.72 & 26.39 \\
\hline
\end{tabular}


Table 2 Characteristics of the studied xenoliths

\begin{tabular}{|c|c|c|c|c|c|c|c|c|}
\hline \multirow{2}{*}{$\begin{array}{l}\text { Xenolith } \\
\text { number }\end{array}$} & \multirow[t]{2}{*}{ Group } & \multirow[t]{2}{*}{ Rock type } & \multicolumn{4}{|c|}{ Modal composition } & \multirow[t]{2}{*}{ Composition of fine-grained aggregates } & \multirow[t]{2}{*}{ Comments } \\
\hline & & & $\mathrm{Ol}$ & Opx & $\mathrm{Cpx}$ & Spl & & \\
\hline $3320 b$ & A & Harzburgite & 71.4 & 28.6 & & & & \\
\hline $3320 \mathrm{c}$ & A & Harzburgite & 82.0 & 17.3 & & 0.7 & $\begin{array}{l}\text { 1) Ol, Cpx, Fsp (Or36-38 Ab61-63) } \\
\text { 2) Cpx, Fsp (Or33 Ab63-65An3) } \\
\text { 3) Ol, Cpx }\end{array}$ & \\
\hline 3334 & A & Harzburgite & 80.1 & 19.5 & & 0.4 & $\begin{array}{l}\text { 1) Ol, Cpx, Or27Ab66An7, analcite, } \\
\text { devitrified glass } \\
\text { 2) O1, Cpx, Opx, Spl, Fsp } \\
\text { (Or35-37Ab63-65An1-2) }\end{array}$ & Cpx I - Spl I cluster; \\
\hline 3323 & A & Harzburgite & 79.1 & 16.1 & 2.4 & 2.4 & $\begin{array}{l}\text { 1) Ol, Fsp (Or22-24Ab69-71An7) } \\
\text { 2) Ol, Cpx, devitrified glass }\end{array}$ & \\
\hline 3324 & A & Harzburgite & 73.8 & 23.1 & 1.8 & 1.3 & & Cpx I - Spl I clusters; \\
\hline 3326 & A & Harzburgite & 79.4 & 17.5 & 2.7 & 0.4 & $\begin{array}{l}\text { 1) Ol, Cpx } \\
\text { 2) Ol, glass/feldspar }\end{array}$ & $\begin{array}{l}\text { Cpx I - Spl I cluster; } \\
\text { O1 III embedded in } \\
\text { interstitial Cpx III; }\end{array}$ \\
\hline 3331 & $\mathrm{~A}$ & Harzburgite & 79.4 & 19.2 & 1.4 & & 1) $\mathrm{Cpx}, \mathrm{Spl}, \mathrm{Ol}, \mathrm{Fsp}(\mathrm{Or} 42 \mathrm{Ab} 55 \mathrm{An} 3)$ & \\
\hline 3333 & $\mathrm{~A}$ & Harzburgite & 76.6 & 20.8 & 1.3 & 1.3 & $\begin{array}{l}\text { 1) } \mathrm{Ol}, \mathrm{Cpx} \text {, devitrified glass } \\
\text { 2) } \mathrm{Pl}, \mathrm{Cpx} \text {, serpentine }\end{array}$ & \\
\hline $3337-2$ & A & Harzburgite & 73.0 & 24.2 & 1.0 & 1.8 & & Cpx I - Spl I cluster; \\
\hline 3327 & $\mathrm{~B}$ & Dunite & 92.8 & 4.1 & 3.1 & & & $\begin{array}{l}\text { Ol III embedded in } \\
\text { interstitial Cpx III }\end{array}$ \\
\hline 3321 & $\mathrm{C}$ & Wehrlite & 51.9 & 4.6 & 40.1 & 3.4 & $\begin{array}{l}\text { 1) Pl (Or1-3Ab24-48An49-75) } \\
\text { 2) Ol, Cpx, Fsp, Pl } \\
\text { (Or1-43Ab24-69An3-75) }\end{array}$ & $\begin{array}{c}\text { vermiform symplectites } \\
\text { S1 (Spl, Cpx) and S2 } \\
\text { (Ol, Opx, Spl, Fsp); }\end{array}$ \\
\hline
\end{tabular}




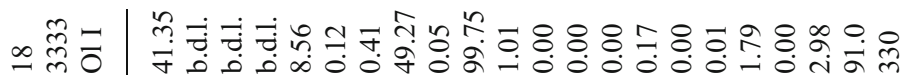

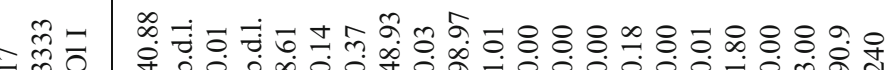

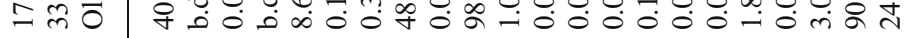

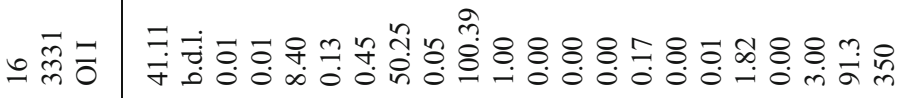

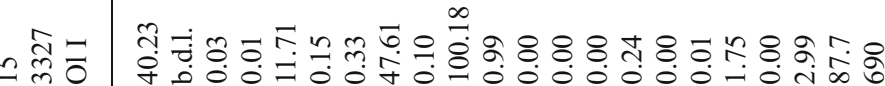

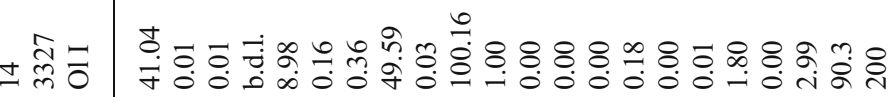

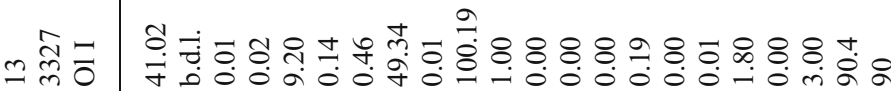

ํํ

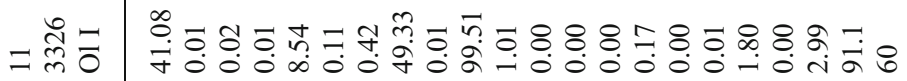

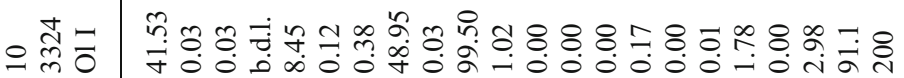

๙

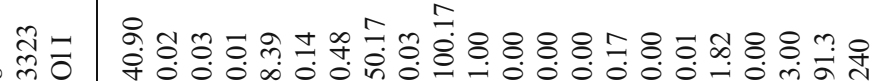

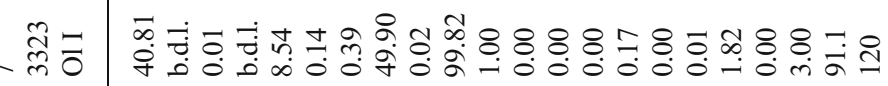

च̄

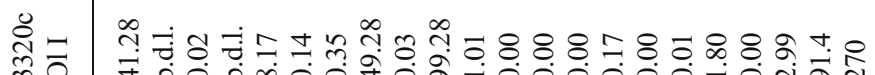

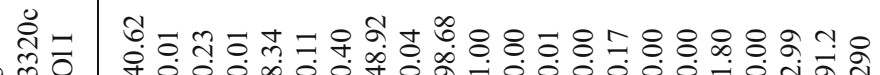

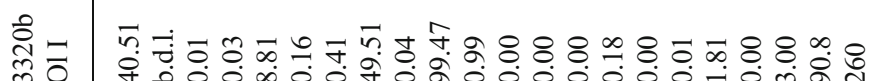
त ळ

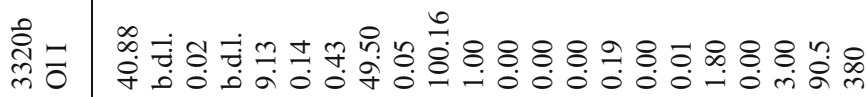

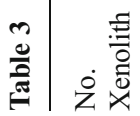

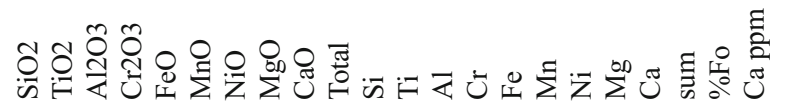

$+\vec{\pi}$ ले

$m \stackrel{+}{m}$ लm ले ले 요 $\bar{c}$ 글 ล 뀨을 กํำ ๙ त ले ন ¿

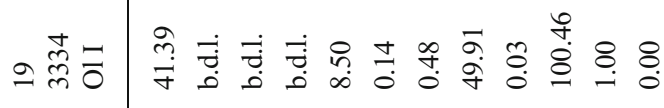

를

$m$

$m \Xi$ $\infty$

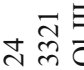
禺目 $\frac{\pi}{5}$ is

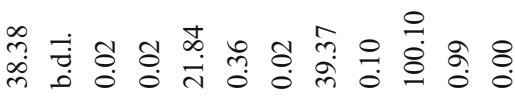

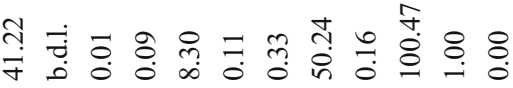

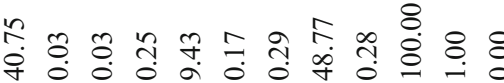

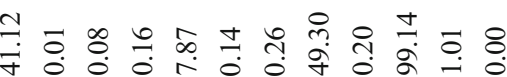
そू.

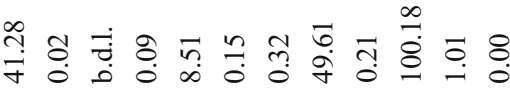

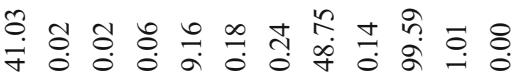
중

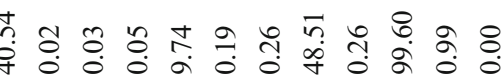

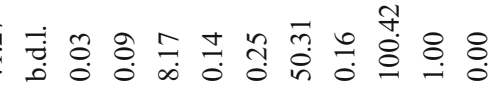

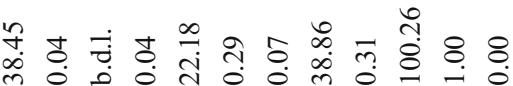
范

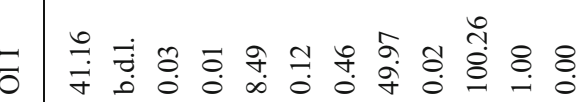

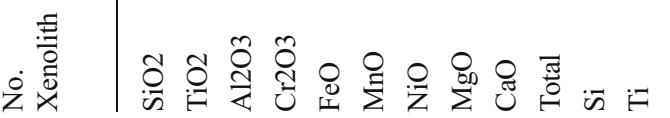

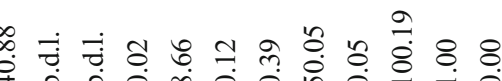




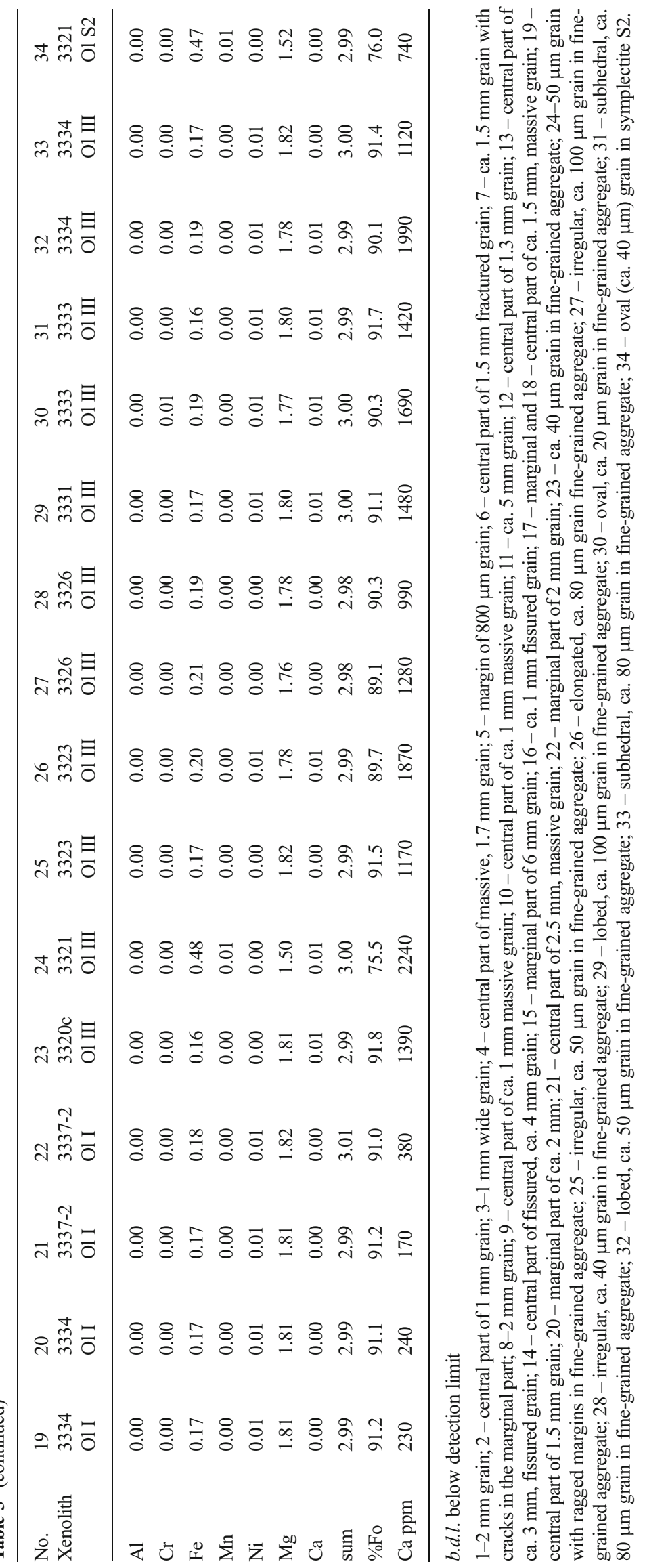


Table 4 Representative chemical analyses and structural formula $(\mathrm{O} 2-=6)$ of pyroxenes from the Steinberg xenoliths

\begin{tabular}{|c|c|c|c|c|c|c|c|c|c|c|c|c|}
\hline No. & 1 & 2 & 3 & 4 & 5 & 6 & 7 & 8 & 9 & 10 & 11 & 12 \\
\hline \multirow[t]{2}{*}{ Xenolith } & $3320 b$ & $3320 \mathrm{c}$ & $3320 \mathrm{c}$ & $3320 \mathrm{c}$ & 3321 & 3323 & 3323 & 3324 & 3326 & 3326 & 3326 & 3327 \\
\hline & Opx I & Opx I & Opx I & Opx I & Opx I & Opx I & Opx I & Opx I & Opx I & Opx I & Opx I & Opx I \\
\hline $\mathrm{SiO} 2$ & 56.60 & 57.58 & 57.21 & 56.33 & 52.96 & 56.56 & 57.20 & 56.94 & 56.60 & 56.39 & 55.57 & 55.41 \\
\hline $\mathrm{TiO} 2$ & 0.02 & 0.01 & 0.02 & 0.05 & 0.03 & b.d.l. & b.d.l. & b.d.l. & 0.02 & 0.05 & 0.26 & 0.22 \\
\hline $\mathrm{A} 12 \mathrm{O} 3$ & 1.82 & 1.00 & 1.91 & 3.10 & 4.24 & 2.37 & 1.58 & 2.08 & 2.06 & 2.57 & 2.80 & 3.19 \\
\hline $\mathrm{Cr} 2 \mathrm{O} 3$ & 0.38 & 0.22 & 0.42 & 0.46 & b.d.l. & 0.62 & 0.26 & 0.51 & 0.56 & 0.77 & 0.49 & 0.78 \\
\hline $\mathrm{FeO}$ & 5.41 & 5.26 & 5.46 & 5.27 & 14.75 & 5.47 & 5.41 & 5.40 & 5.67 & 5.47 & 6.51 & 5.82 \\
\hline $\mathrm{MnO}$ & 0.15 & 0.15 & 0.15 & 0.13 & 0.29 & 0.11 & 0.14 & 0.15 & 0.14 & 0.13 & 0.15 & 0.13 \\
\hline $\mathrm{NiO}$ & 0.07 & 0.08 & 0.11 & 0.08 & 0.01 & 0.07 & 0.11 & 0.08 & 0.09 & 0.06 & 0.09 & 0.09 \\
\hline $\mathrm{MgO}$ & 34.88 & 34.80 & 34.17 & 32.56 & 27.40 & 34.55 & 34.83 & 34.71 & 33.85 & 33.56 & 31.88 & 33.07 \\
\hline $\mathrm{CaO}$ & 0.66 & 0.47 & 0.42 & 1.33 & 0.64 & 0.33 & 0.40 & 0.24 & 0.60 & 0.86 & 1.61 & 1.42 \\
\hline $\mathrm{Na} 2 \mathrm{O}$ & 0.02 & 0.13 & 0.07 & 0.16 & 0.04 & b.d.l. & b.d.l. & b.d.l. & 0.04 & 0.06 & 0.13 & 0.06 \\
\hline $\mathrm{K} 2 \mathrm{O}$ & b.d.l. & b.d.l. & b.d.l. & 0.01 & b.d.l. & b.d.l. & b.d.l. & 0.01 & 0.02 & 0.02 & 0.02 & b.d.l. \\
\hline Total & 100.00 & 99.69 & 99.94 & 99.47 & 100.35 & 100.07 & 99.93 & 100.13 & 99.65 & 99.91 & 99.48 & 100.18 \\
\hline $\mathrm{Si}$ & 1.94 & 1.98 & 1.97 & 1.95 & 1.89 & 1.94 & 1.97 & 1.95 & 1.96 & 1.94 & 1.94 & 1.91 \\
\hline $\mathrm{Ti}$ & 0.00 & 0.00 & 0.00 & 0.00 & 0.00 & 0.00 & 0.00 & 0.00 & 0.00 & 0.00 & 0.01 & 0.01 \\
\hline $\mathrm{Al}$ & 0.07 & 0.04 & 0.08 & 0.13 & 0.18 & 0.10 & 0.06 & 0.08 & 0.08 & 0.10 & 0.11 & 0.13 \\
\hline $\mathrm{Cr}$ & 0.01 & 0.01 & 0.01 & 0.01 & 0.00 & 0.02 & 0.01 & 0.01 & 0.02 & 0.02 & 0.01 & 0.02 \\
\hline $\mathrm{Fe}$ & 0.16 & 0.15 & 0.16 & 0.15 & 0.44 & 0.16 & 0.16 & 0.16 & 0.16 & 0.16 & 0.19 & 0.17 \\
\hline $\mathrm{Mn}$ & 0.00 & 0.00 & 0.00 & 0.00 & 0.01 & 0.00 & 0.00 & 0.00 & 0.00 & 0.00 & 0.00 & 0.00 \\
\hline $\mathrm{Ni}$ & 0.00 & 0.00 & 0.00 & 0.00 & 0.00 & 0.00 & 0.00 & 0.00 & 0.00 & 0.00 & 0.00 & 0.00 \\
\hline $\mathrm{Mg}$ & 1.79 & 1.79 & 1.75 & 1.68 & 1.46 & 1.77 & 1.78 & 1.78 & 1.74 & 1.72 & 1.66 & 1.70 \\
\hline $\mathrm{Ca}$ & 0.02 & 0.02 & 0.02 & 0.05 & 0.02 & 0.01 & 0.01 & 0.01 & 0.02 & 0.03 & 0.06 & 0.05 \\
\hline $\mathrm{Na}$ & 0.00 & 0.01 & 0.00 & 0.01 & 0.00 & 0.00 & 0.00 & 0.00 & 0.00 & 0.00 & 0.01 & 0.00 \\
\hline $\mathrm{K}$ & 0.00 & 0.00 & 0.00 & 0.00 & 0.00 & 0.00 & 0.00 & 0.00 & 0.00 & 0.00 & 0.00 & 0.00 \\
\hline $\mathrm{mg \#}$ & 0.92 & 0.92 & 0.92 & 0.92 & 0.77 & 0.92 & 0.92 & 0.92 & 0.91 & 0.92 & 0.90 & 0.91 \\
\hline No. & 13 & 14 & 15 & 16 & 17 & 18 & 19 & 20 & 21 & 22 & 23 & 24 \\
\hline \multirow[t]{2}{*}{ Xenolith } & 3327 & 3327 & 3331 & 3333 & 3333 & 3334 & 3334 & $3337-2$ & 3334 & 3321 & 3321 & 3321 \\
\hline & Opx I & Opx I & Opx I & Opx I & Opx I & Opx I & Opx I & Opx I & Opx III & Opx S2 & Cpx S1 & Cpx I \\
\hline $\mathrm{SiO} 2$ & 57.08 & 55.02 & 57.21 & 57.13 & 56.73 & 57.20 & 57.62 & 56.39 & 58.13 & 53.58 & 52.41 & 50.77 \\
\hline $\mathrm{TiO} 2$ & b.d.l. & 0.20 & 0.04 & b.d.l. & 0.01 & 0.01 & 0.04 & b.d.l. & 0.02 & 0.01 & 0.12 & 0.32 \\
\hline $\mathrm{A} 12 \mathrm{O} 3$ & 1.77 & 3.28 & 1.63 & 1.30 & 2.18 & 1.89 & 1.14 & 2.16 & 0.64 & 3.73 & 4.15 & 6.11 \\
\hline $\mathrm{Cr} 2 \mathrm{O} 3$ & 0.28 & 0.77 & 0.33 & 0.35 & 0.41 & 0.36 & 0.26 & 0.33 & 0.31 & 0.01 & 0.01 & 0.12 \\
\hline $\mathrm{FeO}$ & 5.74 & 6.82 & 5.38 & 5.41 & 5.66 & 5.50 & 5.42 & 5.50 & 5.40 & 14.81 & 4.70 & 5.21 \\
\hline $\mathrm{MnO}$ & 0.15 & 0.16 & 0.12 & 0.13 & 0.15 & 0.17 & 0.14 & 0.13 & 0.12 & 0.30 & 0.15 & 0.17 \\
\hline $\mathrm{NiO}$ & 0.07 & 0.06 & 0.10 & 0.09 & 0.10 & 0.09 & 0.12 & 0.11 & 0.09 & 0.02 & b.d.1.. & 0.04 \\
\hline $\mathrm{MgO}$ & 34.28 & 31.13 & 34.69 & 34.38 & 34.03 & 34.87 & 35.06 & 34.80 & 35.18 & 27.73 & 14.97 & 13.94 \\
\hline $\mathrm{CaO}$ & 0.25 & 1.93 & 0.50 & 0.46 & 0.44 & 0.43 & 0.30 & 0.50 & 0.55 & 0.37 & 23.06 & 22.40 \\
\hline $\mathrm{Na} 2 \mathrm{O}$ & 0.02 & 0.14 & b.d.l. & 0.04 & 0.06 & b.d.l. & b.d.l. & 0.01 & b.d.l. & b.d.l. & 0.82 & 0.80 \\
\hline $\mathrm{K} 2 \mathrm{O}$ & b.d.l. & 0.02 & 0.03 & b.d.l. & b.d.l. & b.d.l. & b.d.l. & 0.01 & b.d.l. & 0.03 & 0.03 & b.d.l. \\
\hline Total & 99.64 & 99.52 & 100.02 & 99.27 & 99.77 & 100.52 & 100.11 & 99.93 & 100.46 & 100.58 & 100.42 & 99.88 \\
\hline $\mathrm{Si}$ & 1.97 & 1.92 & 1.97 & 1.98 & 1.96 & 1.96 & 1.98 & 1.94 & 1.99 & 1.91 & 1.90 & 1.86 \\
\hline $\mathrm{Ti}$ & 0.00 & 0.01 & 0.00 & 0.00 & 0.00 & 0.00 & 0.00 & 0.00 & 0.00 & 0.00 & 0.00 & 0.01 \\
\hline $\mathrm{Al}$ & 0.07 & 0.14 & 0.07 & 0.05 & 0.09 & 0.08 & 0.05 & 0.09 & 0.03 & 0.16 & 0.18 & 0.26 \\
\hline $\mathrm{Cr}$ & 0.01 & 0.02 & 0.01 & 0.01 & 0.01 & 0.01 & 0.01 & 0.01 & 0.01 & 0.00 & 0.00 & 0.00 \\
\hline $\mathrm{Fe}$ & 0.17 & 0.20 & 0.15 & 0.16 & 0.16 & 0.16 & 0.16 & 0.16 & 0.15 & 0.44 & 0.14 & 0.16 \\
\hline $\mathrm{Mn}$ & 0.00 & 0.00 & 0.00 & 0.00 & 0.00 & 0.00 & 0.00 & 0.00 & 0.00 & 0.01 & 0.00 & 0.00 \\
\hline $\mathrm{Ni}$ & 0.00 & 0.00 & 0.00 & 0.00 & 0.00 & 0.00 & 0.00 & 0.00 & 0.00 & 0.00 & 0.00 & 0.01 \\
\hline $\mathrm{Mg}$ & 1.76 & 1.62 & 1.78 & 1.77 & 1.75 & 1.78 & 1.79 & 1.78 & 1.79 & 1.47 & 0.81 & 0.76 \\
\hline $\mathrm{Ca}$ & 0.01 & 0.07 & 0.02 & 0.02 & 0.02 & 0.02 & 0.01 & 0.02 & 0.02 & 0.01 & 0.90 & 0.88 \\
\hline $\mathrm{Na}$ & 0.00 & 0.01 & 0.00 & 0.00 & 0.00 & 0.00 & 0.00 & 0.00 & 0.00 & 0.00 & 0.06 & 0.06 \\
\hline
\end{tabular}


Table 4 (continued)

\begin{tabular}{|c|c|c|c|c|c|c|c|c|c|c|c|c|}
\hline K & 0.00 & 0.00 & 0.00 & 0.00 & 0.00 & 0.00 & 0.00 & 0.00 & 0.00 & 0.00 & 0.00 & 0.00 \\
\hline $\mathrm{mg} \#$ & 0.91 & 0.89 & 0.92 & 0.92 & 0.91 & 0.92 & 0.92 & 0.92 & 0.92 & 0.77 & 0.85 & 0.83 \\
\hline No. & 25 & 26 & 27 & 28 & 29 & 30 & 31 & 32 & 33 & 34 & 35 & 36 \\
\hline \multirow[t]{2}{*}{ Xenolith } & 3323 & 3323 & 3324 & 3324 & 3324 & 3326 & 3326 & 3331 & 3333 & $3337-2$ & $3337-2$ & $3320 b$ \\
\hline & Cpx I & Cpx I & Cpx I & Cpx I & Cpx I & Cpx I & Cpx I & Cpx I & Cpx I & Cpx I & Cpx I & Cpx II \\
\hline $\mathrm{SiO} 2$ & 54.41 & 53.88 & 52.02 & 54.51 & 54.27 & 53.31 & 53.52 & 53.36 & 54.50 & 53.59 & 53.79 & 53.16 \\
\hline $\mathrm{TiO} 2$ & b.d.l. & 0.03 & 0.15 & b.d.l. & 0.02 & 0.30 & 0.09 & 0.05 & 0.01 & 0.03 & 0.01 & 0.04 \\
\hline $\mathrm{A} 12 \mathrm{O} 3$ & 1.04 & 1.86 & 3.79 & 0.80 & 1.70 & 3.01 & 2.82 & 1.97 & 1.53 & 2.79 & 1.53 & 3.69 \\
\hline $\mathrm{Cr} 2 \mathrm{O} 3$ & 0.25 & 0.37 & 1.39 & 0.23 & 0.33 & 1.08 & 1.32 & 1.43 & 0.49 & 0.57 & 0.38 & 0.83 \\
\hline $\mathrm{FeO}$ & 1.70 & 2.04 & 2.17 & 1.49 & 2.09 & 2.81 & 1.73 & 2.49 & 2.06 & 2.39 & 2.02 & 2.68 \\
\hline $\mathrm{MnO}$ & 0.06 & 0.08 & 0.05 & 0.07 & 0.07 & 0.06 & 0.04 & 0.07 & 0.06 & 0.11 & 0.07 & 0.09 \\
\hline $\mathrm{NiO}$ & 0.04 & 0.08 & 0.06 & 0.05 & 0.08 & 0.04 & 0.04 & 0.03 & 0.03 & 0.06 & 0.04 & 0.02 \\
\hline $\mathrm{MgO}$ & 17.84 & 17.55 & 16.14 & 17.70 & 17.44 & 17.12 & 16.72 & 17.41 & 17.35 & 17.30 & 17.66 & 18.32 \\
\hline $\mathrm{CaO}$ & 24.35 & 23.50 & 23.99 & 24.84 & 23.72 & 21.19 & 22.95 & 22.30 & 23.21 & 23.07 & 24.30 & 20.36 \\
\hline $\mathrm{Na} 2 \mathrm{O}$ & 0.16 & 0.41 & 0.38 & 0.08 & 0.32 & 0.85 & 0.70 & 0.93 & 0.61 & 0.61 & 0.28 & 0.87 \\
\hline $\mathrm{K} 2 \mathrm{O}$ & b.d.l. & 0.01 & 0.01 & b.d.l. & b.d.l. & 0.01 & b.d.l. & 0.01 & b.d.l. & b.d.l. & b.d.l. & b.d.l. \\
\hline Total & 99.87 & 99.81 & 100.13 & 99.77 & 100.04 & 99.77 & 99.93 & 100.05 & 99.86 & 100.50 & 100.07 & 100.5 \\
\hline $\mathrm{Si}$ & 1.97 & 1.96 & 1.89 & 1.98 & 1.97 & 1.94 & 1.94 & 1.93 & 1.98 & 1.93 & 1.95 & 1.91 \\
\hline $\mathrm{Ti}$ & 0.00 & 0.00 & 0.00 & 0.00 & 0.00 & 0.01 & 0.00 & 0.00 & 0.00 & 0.00 & 0.00 & 0.00 \\
\hline $\mathrm{Al}$ & 0.04 & 0.08 & 0.16 & 0.03 & 0.07 & 0.13 & 0.12 & 0.08 & 0.07 & 0.12 & 0.07 & 0.16 \\
\hline $\mathrm{Cr}$ & 0.01 & 0.01 & 0.04 & 0.01 & 0.01 & 0.03 & 0.04 & 0.04 & 0.01 & 0.02 & 0.01 & 0.02 \\
\hline $\mathrm{Fe}$ & 0.05 & 0.06 & 0.07 & 0.05 & 0.06 & 0.09 & 0.05 & 0.08 & 0.06 & 0.07 & 0.06 & 0.08 \\
\hline $\mathrm{Mn}$ & 0.00 & 0.00 & 0.00 & 0.00 & 0.00 & 0.00 & 0.00 & 0.00 & 0.00 & 0.00 & 0.00 & 0.00 \\
\hline $\mathrm{Ni}$ & 0.00 & 0.00 & 0.00 & 0.00 & 0.00 & 0.00 & 0.00 & 0.00 & 0.00 & 0.00 & 0.00 & 0.00 \\
\hline $\mathrm{Mg}$ & 0.97 & 0.95 & 0.87 & 0.96 & 0.94 & 0.93 & 0.90 & 0.94 & 0.94 & 0.93 & 0.95 & 0.98 \\
\hline $\mathrm{Ca}$ & 0.95 & 0.92 & 0.93 & 0.97 & 0.92 & 0.82 & 0.89 & 0.86 & 0.90 & 0.89 & 0.94 & 0.78 \\
\hline $\mathrm{Na}$ & 0.01 & 0.03 & 0.03 & 0.01 & 0.02 & 0.06 & 0.05 & 0.06 & 0.04 & 0.04 & 0.02 & 0.06 \\
\hline K & 0.00 & 0.00 & 0.00 & 0.00 & 0.00 & 0.00 & 0.00 & 0.00 & 0.00 & 0.00 & 0.00 & 0.00 \\
\hline $\mathrm{mg} \#$ & 0.95 & 0.94 & 0.93 & 0.95 & 0.94 & 0.92 & 0.95 & 0.93 & 0.94 & 0.93 & 0.94 & 0.92 \\
\hline No. & 37 & 38 & 39 & 40 & 41 & 42 & 43 & 44 & 45 & 46 & 47 & 48 \\
\hline \multirow[t]{2}{*}{ Xenolith } & $3320 \mathrm{~b}$ & $3320 \mathrm{~b}$ & $3320 \mathrm{c}$ & $3320 \mathrm{c}$ & 3321 & 3321 & 3323 & 3326 & 3331 & 3331 & 3333 & 3333 \\
\hline & Cpx II & Cpx II & Cpx III & Cpx III & Cpx III & Cpx III & Cpx III & Cpx III & Cpx III & Cpx III & Cpx III & Cpx III \\
\hline $\mathrm{SiO} 2$ & 54.30 & 52.64 & 50.86 & 53.99 & 51.75 & 50.59 & 54.38 & 54.01 & 52.64 & 53.46 & 51.11 & 54.03 \\
\hline $\mathrm{TiO} 2$ & 0.02 & 1.06 & 0.23 & 0.17 & 1.66 & 2.17 & 0.09 & 0.60 & 0.75 & 0.79 & 0.04 & 0.24 \\
\hline $\mathrm{A} 12 \mathrm{O} 3$ & 2.67 & 4.72 & 5.94 & 1.95 & 1.96 & 2.89 & 1.13 & 0.95 & 2.78 & 1.43 & 5.63 & 2.24 \\
\hline $\mathrm{Cr} 2 \mathrm{O} 3$ & 0.55 & 0.03 & 2.66 & 0.81 & 0.31 & 0.18 & 0.92 & 1.98 & 1.91 & 1.61 & 2.48 & 1.73 \\
\hline $\mathrm{FeO}$ & 2.82 & 3.10 & 2.71 & 2,69 & 5.18 & 7.19 & 2.23 & 2.82 & 2.32 & 2.19 & 2.70 & 2.00 \\
\hline $\mathrm{MnO}$ & 0.10 & 0.13 & 0.08 & 0.11 & 0.15 & 0.20 & 0.09 & 0.13 & 0.06 & 0.05 & 0.06 & 0.06 \\
\hline $\mathrm{NiO}$ & 0.05 & 0.07 & 0.06 & 0.02 & 0.02 & b.d.l. & 0.02 & 0.05 & 0.05 & 0.08 & 0.08 & 0.06 \\
\hline $\mathrm{MgO}$ & 17.55 & 17.43 & 16.17 & 18.38 & 15.76 & 13.92 & 18.66 & 18.24 & 16.61 & 16.95 & 15.83 & 17.30 \\
\hline $\mathrm{CaO}$ & 21.64 & 20.34 & 20.35 & 21.22 & 22.67 & 22.28 & 21.56 & 19.64 & 22.19 & 22.75 & 21.10 & 22.32 \\
\hline $\mathrm{Na} 2 \mathrm{O}$ & 1.03 & 0.81 & 0.93 & 0.53 & 0.51 & 0.63 & 0.49 & 0.92 & 0.85 & 0.73 & 0.89 & 0.66 \\
\hline $\mathrm{K} 2 \mathrm{O}$ & b.d.l. & b.d.l. & 0.01 & 0.03 & 0.06 & b.d.l. & 0.02 & 0.04 & 0.05 & 0.04 & b.d.l. & 0.10 \\
\hline Total & 100.70 & 100.32 & 100.01 & 99.89 & 100.04 & 100.04 & 99.71 & 99.35 & 100.23 & 100.09 & 99.91 & 100.73 \\
\hline $\mathrm{Si}$ & 1.94 & 1.90 & 1.85 & 1.96 & 1.90 & 1.88 & 1.97 & 1.97 & 1.91 & 1.93 & 1.86 & 1.95 \\
\hline $\mathrm{Ti}$ & 0.00 & 0.03 & 0.01 & 0.00 & 0.05 & 0.06 & 0.00 & 0.02 & 0.02 & 0.00 & 0.00 & 0.01 \\
\hline $\mathrm{Al}$ & 0.11 & 0.20 & 0.25 & 0.08 & 0.08 & 0.13 & 0.05 & 0.04 & 0.12 & 0.12 & 0.24 & 0.10 \\
\hline $\mathrm{Cr}$ & 0.02 & 0.00 & 0.08 & 0.02 & 0.01 & 0.01 & 0.03 & 0.06 & 0.05 & 0.02 & 0.07 & 0.05 \\
\hline $\mathrm{Fe}$ & 0.08 & 0.09 & 0.08 & 0.08 & 0.16 & 0.22 & 0.07 & 0.09 & 0.07 & 0.07 & 0.08 & 0.06 \\
\hline $\mathrm{Mn}$ & 0.00 & 0.00 & 0.00 & 0.00 & 0.00 & 0.01 & 0.00 & 0.00 & 0.00 & 0.00 & 0.00 & 0.00 \\
\hline $\mathrm{Ni}$ & 0.00 & 0.00 & 0.00 & 0.00 & 0.00 & 0.00 & 0.00 & 0.00 & 0.00 & 0.00 & 0.00 & 0.00 \\
\hline $\mathrm{Mg}$ & 0.94 & 0.94 & 0.88 & 0.99 & 0.86 & 0.77 & 1.01 & 0.99 & 0.90 & 0.93 & 0.86 & 0.93 \\
\hline $\mathrm{Ca}$ & 0.83 & 0.79 & 0.79 & 0.82 & 0.89 & 0.89 & 0.84 & 0.77 & 0.86 & 0.89 & 0.82 & 0.86 \\
\hline $\mathrm{Na}$ & 0.07 & 0.06 & 0.07 & 0.04 & 0.04 & 0.05 & 0.03 & 0.06 & 0.06 & 0.04 & 0.06 & 0.05 \\
\hline K & 0.00 & 0.00 & 0.00 & 0.00 & 0.00 & 0.00 & 0.00 & 0.00 & 0.00 & 0.00 & 0.00 & 0.00 \\
\hline $\mathrm{mg} \#$ & 0.92 & 0.91 & 0.91 & 0.92 & 0.84 & 0.78 & 0.93 & 0.92 & 0.93 & 0.93 & 0.91 & 0.94 \\
\hline No. & 49 & 50 & 51 & 52 & 53 & 54 & 55 & 56 & 57 & 58 & 59 & 60 \\
\hline \multirow[t]{2}{*}{ Xenolith } & 3334 & 3334 & $3320 \mathrm{c}$ & $3320 \mathrm{c}$ & 3323 & 3323 & 3326 & 3331 & 3333 & 3333 & 3334 & 3334 \\
\hline & Cpx III & Cpx III & Cpx III & Cpx III & Cpx III & Cpx III & Cpx III & Cpx III & Cpx III & Cpx III & Cpx III & Cpx III \\
\hline $\mathrm{SiO} 2$ & 51.45 & 54.87 & 53.20 & 51.77 & 53.41 & 53.63 & 53.94 & 53.92 & 54.31 & 55.06 & 54.54 & 54.06 \\
\hline TiO2 & 0.17 & 0.08 & 0.14 & 0.14 & 0.04 & 0.02 & 0.77 & 0.70 & 0.60 & 0.02 & 0.65 & 0.51 \\
\hline $\mathrm{A} 12 \mathrm{O} 3$ & 4.62 & 1.37 & 2.92 & 4.63 & 2.04 & 1.90 & 0.74 & 1.01 & 1.19 & 1.39 & 1.11 & 0.92 \\
\hline $\mathrm{Cr} 2 \mathrm{O} 3$ & 4.04 & 0.93 & 1.36 & 2.75 & 0.44 & 0.34 & 1.75 & 0.71 & 0.49 & 1.01 & 0.66 & 1.28 \\
\hline $\mathrm{FeO}$ & 2.59 & 3.14 & 2.36 & 2.75 & 2.07 & 2.31 & 2.99 & 3.00 & 2.78 & 3.13 & 2.50 & 2.23 \\
\hline $\mathrm{MnO}$ & 0.07 & 0.13 & 0.09 & 0.08 & 0.06 & 0.07 & 0.13 & 0.14 & 0.09 & 0.13 & 0.08 & 0.08 \\
\hline $\mathrm{NiO}$ & 0.05 & 0.05 & 0.05 & 0.07 & 0.05 & 0.08 & 0.06 & 0.02 & 0.03 & 0.05 & 0.03 & 0.06 \\
\hline $\mathrm{MgO}$ & 16.54 & 20.75 & 17.47 & 17.48 & 17.29 & 17.53 & 18.22 & 17.72 & 18.69 & 21.46 & 18.30 & 17.89 \\
\hline
\end{tabular}


Table 4 (continued)

\begin{tabular}{|c|c|c|c|c|c|c|c|c|c|c|c|c|}
\hline $\mathrm{CaO}$ & 19.40 & 18.74 & 21.52 & 19.38 & 23.95 & 23.89 & 20.24 & 22.58 & 20.91 & 17.46 & 21.91 & 22.23 \\
\hline $\mathrm{Na} 2 \mathrm{O}$ & 1.28 & 0.48 & 0.61 & 0.87 & 0.26 & 0.32 & 0.83 & 0.62 & 0.55 & 0.43 & 0.57 & 0.71 \\
\hline $\mathrm{K} 2 \mathrm{O}$ & 0.01 & b.d.1. & 0.02 & b.d.1. & b.d.l. & 0.02 & b.d.l. & b.d.l. & 0.05 & 0.01 & 0.01 & b.d.l. \\
\hline Total & 100.22 & 100.53 & 99.74 & 99.93 & 99.61 & 100.11 & 99.66 & 100.43 & 99.69 & 100.15 & 100.36 & 99.97 \\
\hline $\mathrm{Si}$ & 1.87 & 1.96 & 1.93 & 1.88 & 1.95 & 1.95 & 1.96 & 1.95 & 1.97 & 1.97 & 1.97 & 1.96 \\
\hline $\mathrm{Ti}$ & 0.00 & 0.00 & 0.00 & 0.00 & 0.00 & 0.00 & 0.02 & 0.02 & 0.02 & 0.00 & 0.02 & 0.01 \\
\hline $\mathrm{Al}$ & 0.20 & 0.06 & 0.12 & 0.20 & 0.09 & 0.08 & 0.03 & 0.04 & 0.05 & 0.06 & 0.05 & 0.04 \\
\hline $\mathrm{Cr}$ & 0.12 & 0.03 & 0.04 & 0.08 & 0.01 & 0.01 & 0.05 & 0.02 & 0.01 & 0.03 & 0.02 & 0.04 \\
\hline $\mathrm{Fe}$ & 0.08 & 0.09 & 0.07 & 0.08 & 0.06 & 0.07 & 0.09 & 0.09 & 0.08 & 0.09 & 0.08 & 0.07 \\
\hline $\mathrm{Mn}$ & 0.00 & 0.00 & 0.00 & 0.00 & 0.00 & 0.00 & 0.00 & 0.00 & 0.00 & 0.00 & 0.00 & 0.00 \\
\hline $\mathrm{Ni}$ & 0.00 & 0.00 & 0.00 & 0.00 & 0.00 & 0.00 & 0.00 & 0.00 & 0.00 & 0.00 & 0.00 & 0.00 \\
\hline $\mathrm{Mg}$ & 0.90 & 1.11 & 0.95 & 0.95 & 0.94 & 0.95 & 0.99 & 0.95 & 1.01 & 1.14 & 0.98 & 0.97 \\
\hline $\mathrm{Ca}$ & 0.76 & 0.72 & 0.84 & 0.75 & 0.94 & 0.93 & 0.79 & 0.87 & 0.81 & 0.67 & 0.85 & 0.87 \\
\hline $\mathrm{Na}$ & 0.09 & 0.03 & 0.04 & 0.06 & 0.02 & 0.02 & 0.06 & 0.04 & 0.04 & 0.03 & 0.04 & 0.05 \\
\hline $\mathrm{K}$ & 0.00 & 0.00 & 0.00 & 0.00 & 0.00 & 0.00 & 0.00 & 0.00 & 0.00 & 0.00 & 0.00 & 0.00 \\
\hline $\mathrm{mg \#}$ & 0.92 & 0.92 & 0.93 & 0.92 & 0.94 & 0.93 & 0.92 & 0.91 & 0.92 & 0.92 & 0.93 & 0.93 \\
\hline No. & 61 & 62 & 63 & 64 & 65 & & & & & & & \\
\hline \multirow[t]{2}{*}{ Xenolith } & 3326 & 3326 & 3326 & 3327 & 3327 & & & & & & & \\
\hline & Cpx III & Cpx III & Cpx III & Cpx III & Cpx III & & & & & & & \\
\hline $\mathrm{SiO} 2$ & 51.69 & 50.58 & 50.81 & 53.84 & 49.88 & & & & & & & \\
\hline $\mathrm{TiO} 2$ & 1.09 & 1.03 & 0.83 & 0.62 & 1.29 & & & & & & & \\
\hline $\mathrm{A} 12 \mathrm{O} 3$ & 3.65 & 5.65 & 4.78 & 1.54 & 5.12 & & & & & & & \\
\hline $\mathrm{Cr} 2 \mathrm{O} 3$ & 1.62 & 1.51 & 1.22 & 1.41 & 1.27 & & & & & & & \\
\hline $\mathrm{FeO}$ & 2.87 & 3.69 & 5.14 & 3.21 & 4.78 & & & & & & & \\
\hline $\mathrm{MnO}$ & 0.08 & 0.09 & 0.12 & 0.10 & 0.10 & & & & & & & \\
\hline $\mathrm{NiO}$ & 0.03 & 0.03 & 0.06 & 0.06 & 0.06 & & & & & & & \\
\hline $\mathrm{MgO}$ & 16.07 & 16.10 & 15.61 & 17.60 & 15.08 & & & & & & & \\
\hline $\mathrm{CaO}$ & 22.08 & 19.86 & 20.13 & 21.69 & 22.35 & & & & & & & \\
\hline $\mathrm{Na} 2 \mathrm{O}$ & 0.67 & 1.01 & 0.87 & 0.73 & 0.59 & & & & & & & \\
\hline $\mathrm{K} 2 \mathrm{O}$ & 0.01 & b.d.l. & 0.01 & 0.03 & b.d.l. & & & & & & & \\
\hline Total & 99.85 & 99.55 & 99.57 & 100.81 & 100.50 & & & & & & & \\
\hline $\mathrm{Si}$ & 1.89 & 1.85 & 1.87 & 1.94 & 1.82 & & & & & & & \\
\hline $\mathrm{Ti}$ & 0.03 & 0.03 & 0.02 & 0.02 & 0.04 & & & & & & & \\
\hline $\mathrm{Al}$ & 0.16 & 0.24 & 0.21 & 0.07 & 0.22 & & & & & & & \\
\hline $\mathrm{Cr}$ & 0.05 & 0.04 & 0.04 & 0.04 & 0.04 & & & & & & & \\
\hline $\mathrm{Fe}$ & 0.09 & 0.11 & 0.16 & 0.10 & 0.15 & & & & & & & \\
\hline $\mathrm{Mn}$ & 0.00 & 0.00 & 0.00 & 0.00 & 0.00 & & & & & & & \\
\hline $\mathrm{Ni}$ & 0.00 & 0.00 & 0.00 & 0.00 & 0.00 & & & & & & & \\
\hline $\mathrm{Mg}$ & 0.88 & 0.88 & 0.86 & 0.95 & 0.82 & & & & & & & \\
\hline $\mathrm{Ca}$ & 0.86 & 0.78 & 0.79 & 0.84 & 0.87 & & & & & & & \\
\hline $\mathrm{Na}$ & 0.05 & 0.07 & 0.06 & 0.05 & 0.04 & & & & & & & \\
\hline $\mathrm{K}$ & 0.00 & 0.00 & 0.00 & 0.00 & 0.00 & & & & & & & \\
\hline $\mathrm{mg \#}$ & 0.91 & 0.89 & 0.84 & 0.91 & 0.85 & & & & & & & \\
\hline
\end{tabular}

b.d.l. below detection limit

Orthopyroxene: 1-3 mm grain with clinopyroxene II/spinel II lamellae; 2 - marginal part of $400 \mu \mathrm{m}$ grain with clinopyroxene III rims; 3 - central part of $3.5 \mathrm{~mm}$ grain with clinopyroxene II/spinel II lamellae; 4 - central part of $1.2 \mathrm{~mm}$ grain with clinopyroxene II/spinel II lamellae; 5 - central part of the large grain; 6 - central part of $800 \mu \mathrm{m}$ grain; 7 - marginal part of $1.2 \mathrm{~mm}$ grain with clinopyroxene III rims, located close to fine-grained aggregate; 8 central part of clear grain; 9-2 mm grain with clinopyroxene lamellae; 10 - central part of $2 \mathrm{~mm}$ grain with clinopyroxene lamealle; 11 - marginal part of $1 \mathrm{~mm}$ grain with clinopyroxene rims and lamealle; 12 - central part of $750 \mu \mathrm{m}$ perforated grain with clinopyroxene rims; $13-$ large $(2.5 \mathrm{~mm})$, fissured grain; 14 - central part of $2 \mathrm{~mm}$ fissured grain; 15 - marginal part of $2 \mathrm{~mm}$, elongated grain with clinopyroxene lamellae and rims; 16 - marginal part and 17 - central part of $800 \mu \mathrm{m}$ grain; 18 - perforated, $2.3 \mathrm{~mm}$ grain with clinopyroxene dots; 19 - marginal part (without lamellae) of $500 \mu \mathrm{m}$ grain; 20 $100 \mu \mathrm{m}$ part of fissured grain; 21 - irregular, ca. $80 \mu \mathrm{m}$ grain; 22- elongated, ragged, ca. $60 \mu \mathrm{m}$ grain in S2 symplectite

Clinopyroxene: 23 - part of S1 symplectite; $24-1.5 \mathrm{~mm}$, fissured grain with spinel inclusions; 25 - clear, marginal part of $400 \mu \mathrm{m}$ grain with lathy lamellae of spinel; 26 - marginal, clear part of $800 \mu \mathrm{m}$ grain with spinel lathy lamellae, in contact with basanite; 27 - marginal part of $1 \mathrm{~mm}$ grain with lathy lamellae of spinel; 28-300 $\mu \mathrm{m}$ grain, part of clinopyroxene-spinel symplectite; 29 - marginal part of $900 \mu \mathrm{m}$ grain with lathy lamellae of spinel; 30 - marginal part of $600 \mu \mathrm{m}$ grain; 31 - central part of $230 \mu \mathrm{m}$ grain; 32-300 $\mu \mathrm{m}$, perforated grain with lathy lamellae of spinel; 33 - central part of perforated, $800 \mu \mathrm{m}$ grain with lathy lamellae of spinel; 34 - marginal part of $400 \mu \mathrm{m}$ grain with lathy lamellae of spinel; 35 - central part of $600 \mu \mathrm{m}$ grain with spinel inclusions; 36 - irregular $60 \mu \mathrm{m}$ intergrowth in orthopyroxene I; 37-80 $\mu \mathrm{m}$ length lathy lamella in orthopyroxene I; 38-80 $\mu \mathrm{m}$ intergrowth in orthopyroxene I; 39-50 $\mu \mathrm{m}$ ragged grain in fine-grained aggregate; 40 - ca. $25 \mu \mathrm{m}$ ragged grain in fine-grained aggregate; 41,42 - ca. $150 \mu \mathrm{m}$ poikilitic, inhomogeneous grain in fine-grained aggregate; 43 - ca. $50 \mu \mathrm{m}$ length grain in fine-grained aggregate; 44 - ca. $10 \mu \mathrm{m}$ grain in finegrained aggregate; 45 - ca. $30 \mu \mathrm{m}$ and 46 - ca. $50 \mu \mathrm{m}$ spongy grain in fine-grained aggregate; 47 - ca. $20 \mu \mathrm{m}$ oval grain in fine-grained aggregate; 48 ca. $20 \mu \mathrm{m}$ oval grain in fine-grained aggregate; 49 - perforated grain in fine-grained aggregate; 50 - thin rims on orthopyroxene III grain in fine-grained aggregate; 51, 52, 53, 54, 55, 56, 57, 58, 59, 60 - vermicular rims on orthopyroxene I; 61, 62, 63, 64, 65 - interstitial clinopyroxene III 
Table 5 Representative chemical analyses and structural formulae of spinels (Cations=3) from the Steinberg xenoliths

\begin{tabular}{|c|c|c|c|c|c|c|c|c|c|c|c|c|c|c|}
\hline $\begin{array}{l}\text { No. } \\
\text { Xenolith }\end{array}$ & $\begin{array}{l}1 \\
3323 \\
\text { Spl I }\end{array}$ & $\begin{array}{l}2 \\
3324 \\
\text { Spl I }\end{array}$ & $\begin{array}{l}3 \\
3326 \\
\text { Spl I }\end{array}$ & $\begin{array}{l}4 \\
3326 \\
\text { Spl I }\end{array}$ & $\begin{array}{l}5 \\
3334 \\
\text { Spl I }\end{array}$ & $\begin{array}{l}6 \\
3334 \\
\text { Spl I }\end{array}$ & $\begin{array}{l}7 \\
3337-2 \\
\text { Spl I }\end{array}$ & $\begin{array}{l}8 \\
3320 b \\
\text { Spl II }\end{array}$ & $\begin{array}{l}9 \\
3320 b \\
\text { Spl II }\end{array}$ & $\begin{array}{l}10 \\
3337-2 \\
\text { Spl II }\end{array}$ & $\begin{array}{l}11 \\
3331 \\
\text { Spl III }\end{array}$ & $\begin{array}{l}12 \\
3334 \\
\text { Spl III }\end{array}$ & $\begin{array}{l}13 \\
3321 \\
\text { Spl S1 }\end{array}$ & $\begin{array}{l}14 \\
3321 \\
\text { Spl S2 }\end{array}$ \\
\hline $\mathrm{SiO} 2$ & b.d.l. & b.d.l. & 0.02 & 0.01 & 0.01 & 0.03 & 0.02 & 0.08 & 0.09 & 0.04 & 0.06 & 0.18 & 0.06 & 0.03 \\
\hline $\mathrm{TiO} 2$ & 0.03 & b.d.l. & 0.07 & 0.12 & 0.11 & 0.06 & 0.02 & 1.73 & 0.11 & 0.04 & 0.62 & 1.21 & 0.01 & 0.02 \\
\hline $\mathrm{A} 12 \mathrm{O} 3$ & 29.60 & 29.54 & 28.01 & 27.86 & 23.61 & 25.42 & 32.64 & 24.28 & 45.37 & 39.24 & 15.73 & 27.92 & 63.44 & 65.65 \\
\hline $\mathrm{Cr} 2 \mathrm{O} 3$ & 37.77 & 37.43 & 39.82 & 40.82 & 40.87 & 39.90 & 34.47 & 34.53 & 20.14 & 29.82 & 49.91 & 37.51 & b.d.l. & 0.18 \\
\hline $\mathrm{FeO}$ & 16.41 & 16.40 & 16.03 & 14.46 & 19.77 & 18.63 & 16.12 & 23.02 & 12.65 & 11.38 & 19.33 & 15.74 & 19.41 & 16.07 \\
\hline $\mathrm{MnO}$ & 0.12 & 0.13 & 0.12 & 0.14 & 0.17 & 0.16 & 0.14 & 0.22 & 0.13 & 0.09 & 0.25 & 0.13 & 0.14 & 0.16 \\
\hline $\mathrm{NiO}$ & 0.18 & 0.19 & 0.14 & 0.12 & 0.19 & 0.19 & 0.20 & 0.26 & 0.39 & 0.24 & 0.09 & 0.19 & 0.10 & 0.09 \\
\hline $\mathrm{MgO}$ & 15.57 & 15.87 & 15.73 & 15.99 & 14.59 & 14.81 & 16.12 & 14.65 & 20.05 & 18.13 & 12.69 & 15.53 & 16.56 & 17.98 \\
\hline $\mathrm{ZnO}$ & b.d.l. & b.d.l. & 0.12 & 0.17 & b.d.l. & 0.02 & 0.13 & n.a. & n.a. & 0.09 & n.a. & n.a. & 0.28 & 0.22 \\
\hline $\mathrm{CaO}$ & 0.01 & 0.01 & b.d.l. & b.d.l. & b.d.l. & b.d.l. & b.d.1. & 0.05 & 0.05 & 0.27 & 0.05 & 0.06 & 0.20 & b.d.l. \\
\hline Total & 99.68 & 99.59 & 100.06 & 99.70 & 99.32 & 99.22 & 99.86 & 98.85 & 99.25 & 99.34 & 98.77 & 98.52 & 100.19 & 100.39 \\
\hline $\mathrm{Si}$ & 0.00 & 0.00 & 0.00 & 0.00 & 0.00 & 0.00 & 0.00 & 0.00 & 0.00 & 0.00 & 0.00 & 0.01 & 0.00 & 0.00 \\
\hline $\mathrm{Ti}$ & 0.00 & 0.00 & 0.00 & 0.00 & 0.00 & 0.00 & 0.00 & 0.04 & 0.00 & 0.00 & 0.01 & 0.03 & 0.00 & 0.00 \\
\hline $\mathrm{Al}$ & 1.03 & 1.02 & 0.97 & 0.97 & 0.84 & 0.90 & 1.11 & 0.87 & 1.45 & 1.30 & 0.59 & 0.98 & 1.93 & 1.96 \\
\hline $\mathrm{Cr}$ & 0.88 & 0.87 & 0.93 & 0.95 & 0.98 & 0.95 & 0.79 & 0.83 & 0.43 & 0.66 & 1.26 & 0.89 & 0.00 & 0.00 \\
\hline $\mathrm{Fe}+3$ & 0.09 & 0.11 & 0.10 & 0.08 & 0.17 & 0.14 & 0.10 & 0.22 & 0.12 & 0.04 & 0.12 & 0.07 & 0.08 & 0.04 \\
\hline $\mathrm{Fe}+2$ & 0.31 & 0.30 & 0.30 & 0.28 & 0.33 & 0.33 & 0.29 & 0.36 & 0.16 & 0.22 & 0.40 & 0.33 & 0.34 & 0.30 \\
\hline $\mathrm{Mn}$ & 0.00 & 0.00 & 0.00 & 0.00 & 0.00 & 0.00 & 0.00 & 0.01 & 0.01 & 0.00 & 0.01 & 0.00 & 0.01 & 0.01 \\
\hline $\mathrm{Ni}$ & 0.00 & 0.00 & 0.00 & 0.00 & 0.00 & 0.00 & 0.00 & 0.01 & 0.01 & 0.01 & 0.00 & 0.00 & 0.00 & 0.00 \\
\hline $\mathrm{Mg}$ & 0.68 & 0.70 & 0.69 & 0.70 & 0.66 & 0.67 & 0.70 & 0.66 & 0.81 & 0.87 & 0.60 & 0.69 & 0.64 & 0.68 \\
\hline $\mathrm{cr} \#$ & 0.46 & 0.46 & 0.49 & 0.50 & 0.54 & 0.51 & 0.41 & 0.49 & 0.23 & 0.34 & 0.68 & 0.47 & 0.00 & 0.00 \\
\hline $\mathrm{mg \#}$ & 0.63 & 0.63 & 0.64 & 0.66 & 0.57 & 0.59 & 0.64 & 0.53 & 0.74 & 0.74 & 0.54 & 0.64 & 0.60 & 0.67 \\
\hline
\end{tabular}




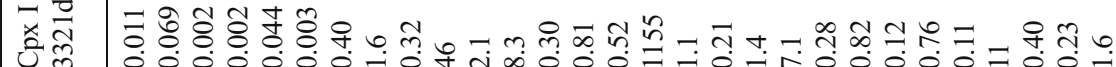

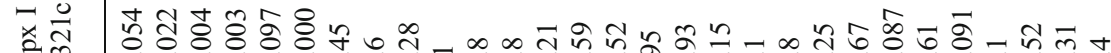
चि

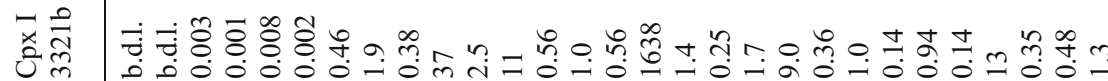

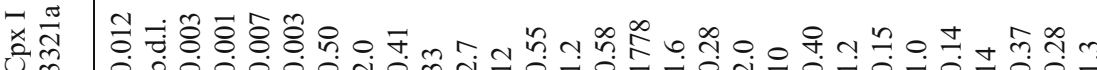

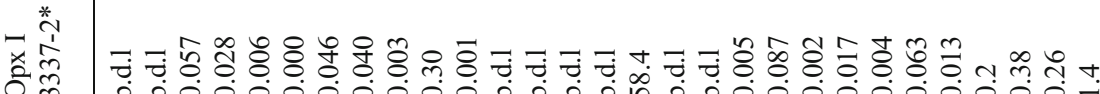

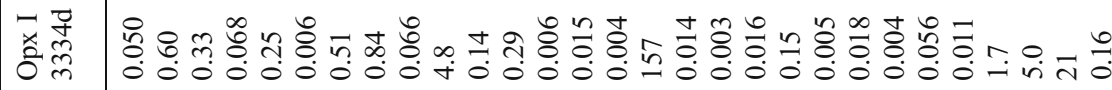

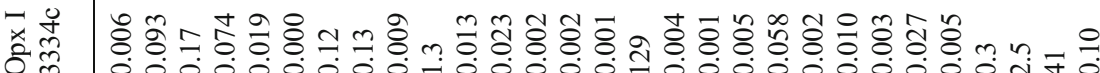

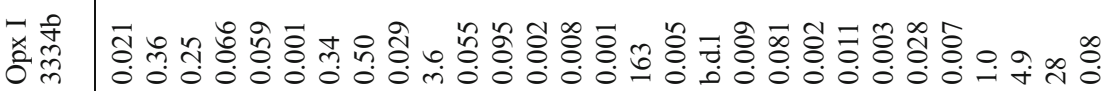

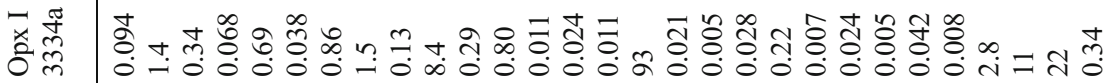

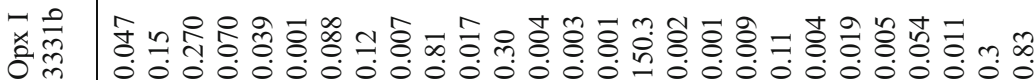

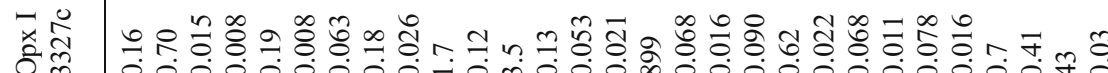

×

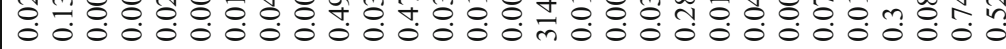

츌 Oे ॠ

マ* ช ठ̊

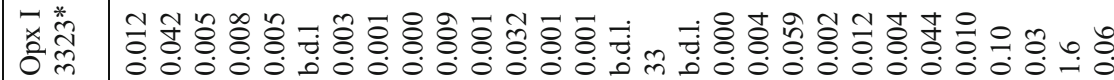
ॠ* ․ㅜㅇ

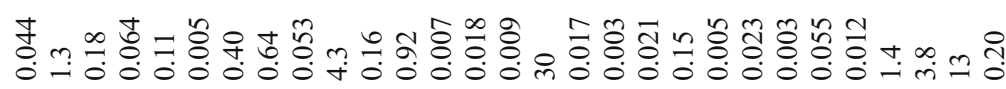

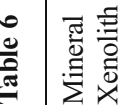

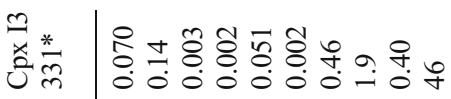

च芯

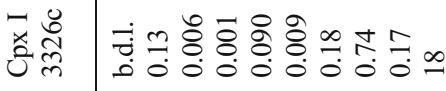

च危

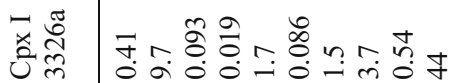

苍先 m

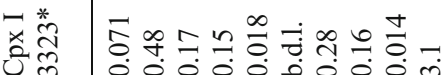

चี

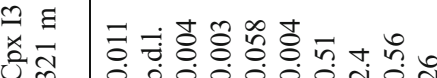

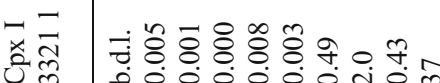

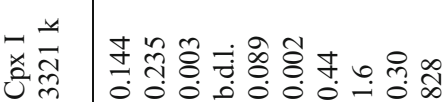

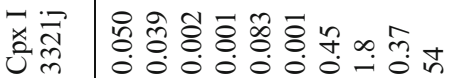

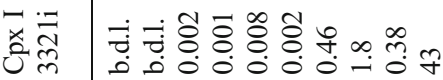

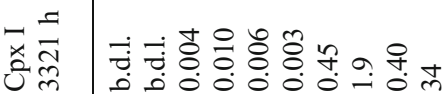

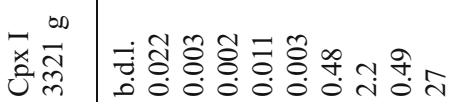

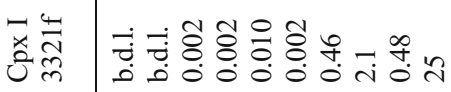

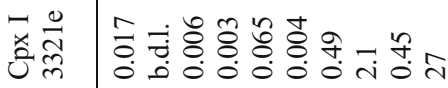

可 


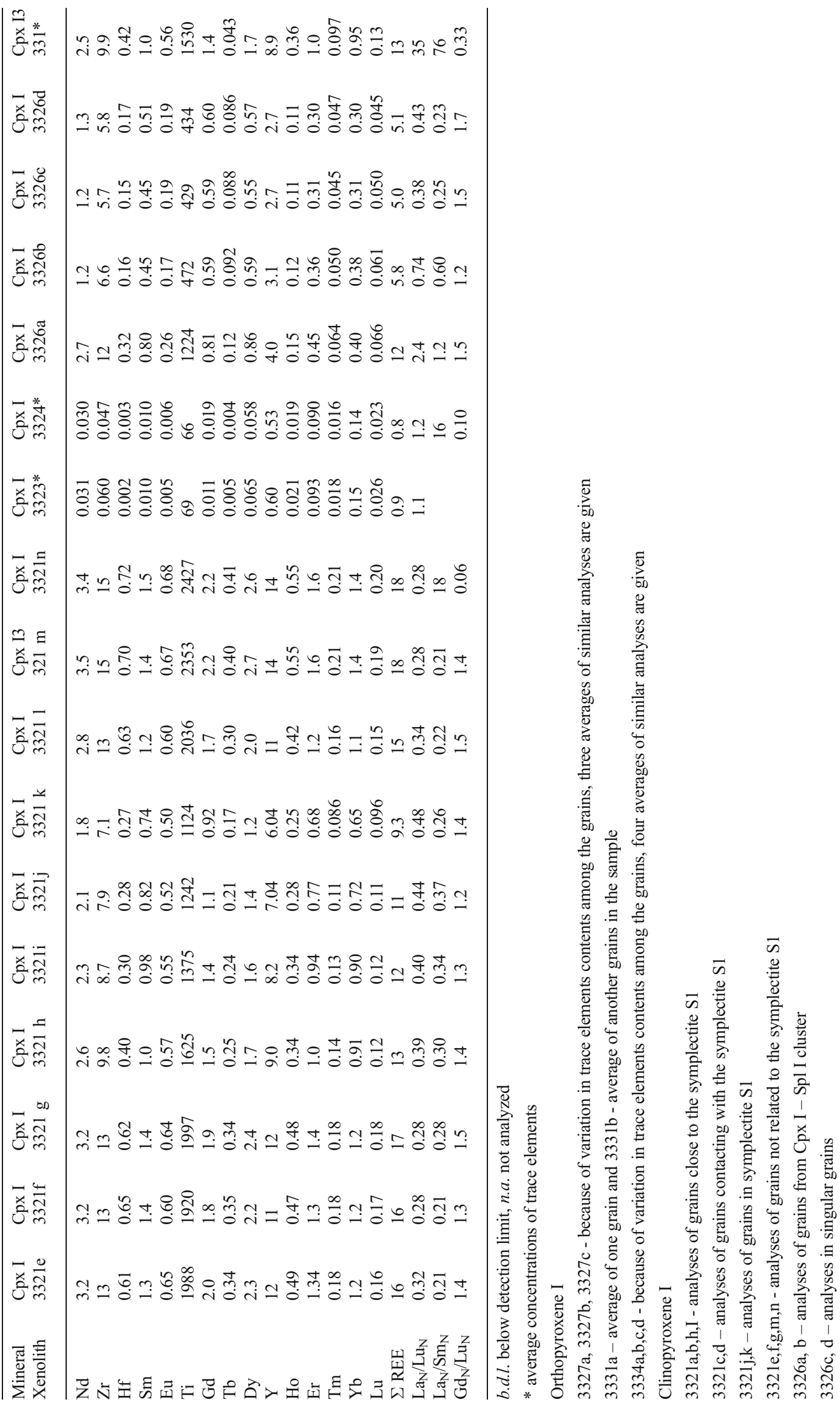


Table 7 Representative chemical analyses of sulfides from the Steinberg wehrlite xenolith (wt. \%)

\begin{tabular}{lllllll}
\hline $\begin{array}{l}\text { No. } \\
\text { Xenolith }\end{array}$ & 1 & 2 & 3 & 4 & 5 & 6 \\
\hline $\mathrm{Si}$ & 0.05 & 0.07 & 0.40 & 0.07 & 0.05 & 0.02 \\
$\mathrm{Mg}$ & b.d.1. & b.d.1. & 0.01 & 0.01 & b.d.1. & b.d.1. \\
$\mathrm{Al}$ & 0.07 & 0.18 & 0.15 & 0.19 & 0.16 & 0.04 \\
$\mathrm{~S}$ & 38.85 & 38.74 & 35.89 & 39.33 & 35.33 & 39.14 \\
$\mathrm{Cr}$ & b.d.1. & b.d.1. & b.d.1. & 0.02 & 0.01 & 0.01 \\
$\mathrm{Fe}$ & 57.75 & 58.27 & 39.82 & 60.48 & 43.29 & 60.55 \\
$\mathrm{Ni}$ & 2.34 & 2.15 & 3.66 & 0.40 & 3.91 & 0.29 \\
$\mathrm{Co}$ & 0.43 & 0.32 & 0.19 & 0.01 & 0.31 & b.d.1. \\
$\mathrm{Cu}$ & 0.85 & 0.76 & 18.72 & 0.40 & 15.56 & 0.05 \\
$\mathrm{Total}$ & 100.32 & 100.48 & 98.82 & 100.90 & 98.60 & 100.09 \\
\hline
\end{tabular}

*b.d.l. below detection limit

1 (core) - 2-3 (rim) parts of ca. $600 \mu \mathrm{m}$, cracked grain; 4 (core), 5 (rim) parts of oval, $200 \mu \mathrm{m}$ grain; 6 - core part of $100 \mu \mathrm{m}$ grain

Open Access This article is distributed under the terms of the Creative Commons Attribution 4.0 International License (http:// creativecommons.org/licenses/by/4.0/), which permits unrestricted use, distribution, and reproduction in any medium, provided you give appropriate credit to the original author(s) and the source, provide a link to the Creative Commons license, and indicate if changes were made.

\section{References}

Ackerman L, Mahlen N, Jelínek E, Medaris GJ, Ulrych J, Strnad L, Mihaljevič M (2007) Geochemistry and evolution of subcontinental lithospheric mantle in central Europe: evidence from peridotite xenoliths of the Kozákov Volcano, Czech Republic. J Petrol 48:22352260

Ackerman L, Špaček P, Medaris G Jr, Hegner E, Svojtka M, Ulrych J (2012) Geochemistry and petrology of pyroxenite xenoliths from Cenozoic alkaline basalts, Bohemian Massif. J Geosci 58:199-219

Ackerman L, Špaček P, Magna T, Ulrych J, Svojtka M, Hegner E, Balogh K (2013) Alkaline and carbonate-rich melt metasomatism and melting of subcontinental lithospheric mantle: evidence from Mantle Xenoliths, NE Bavaria, Bohemian Massif. J Petrol 54:2597-2633

Ackerman L, Medaris GJ, Špaček P, Ulrych J (2015) Geochemical and petrological constraints on mantle composition of the Ohrě (Eger) rift, Bohemian Massif: peridotite xenoliths from the Česke Strĕdohoří Volcanic complex and northern Bohemia. Int J Earth Sci. doi:10.1007/s00531-014-1054-1

Arai S (1994) Characterization of spinel peridotites by olivine - spinel compositional relationship: review and interpretation. Chem Geol 113:191-204

Bianchini G, Beccaluva L, Bonadiman C, Nowell G, Pearson G, Siena F, Wilson M (2007) Evidence of diverse depletion and metasomatic events in harzburgite-lherzolite mantle xenoliths from the Iberian plate (Olot, NE Spain): Implications for lithosphere accretionary processes. Lithos 94:25-45

Blusztajn J, Shimizu N (1994) The Trace-element variations in clinopyroxenes from spinel peridotite xenoliths from Southwest Poland. Chem Geol 111:227-243

Bogaard PJF, Wörner G (2003) Petrogenesis of basanitic to tholeiitic volcanic rocks from the Miocene Vegelsberg, Central Germany. J Petrol 44:569-602
Brey GP, Köhler T (1990) Geothermobarometry in four-phase lherzolites II. new thermobarometers and practical assessment of existing thermobarometers. J Petrol 31:1353-1378

Brey GP, Köhler TP, Nickel EH (1990) Geothermobarometry in four-phase lherzolites I. experimental results from 10 to $60 \mathrm{~kb}$. J Petrol 31:1313-1352

Büchner J, Tietz O, Viereck L, Abratis M, Suhr P (2015) Volcanology, geochemistry and age of the lausitz volcanic field. Int J Earth Sci. doi: 10.1007/s00531-015-1165-3

Bukała M, Puziewicz J, Ntaflos T, Wojtulek P (2015) Preliminary data on sulfides from mantle xenoliths from Wilcza Góra and Krzeniów basanites (SW Poland) Geophysical Research Abstracts Vol. 17, EGU2015-4339

Coltorti M, Bonadiman C, Hinton RW, Siena F, Upton BGJ (1999) Carbonatite metasomatism of the oceanic upper mantle: evidnce from clinopyroxenes and glasses in ultramafic xenoliths of Grande Comore, Indian Ocean. J Petrol 40:133-165

Deer WA, Howie RA, Zussman J (1993) An introduction to the rockforming minerals. Longman Scientific \& Technical, New York

Downes H (2001) Formation and modification of the shallow subcontinental lithospheric mantle: a review of geochemical evidence from ultramafic xenolith suites and tectonically emplaced ultramafic massifs of Western and Central Europe. J Petrol 42:233-250

Downes H, Reichow MK, Mason PRD, Beard AD, Thirlwall MF (2003) Mantle domains in the lithosphere beneath the French Massif Central: trace element and isotopic evidence from mantle clinopyroxenes. Chem Geol 200:71-87

Downes H, de Vries C, Wittig N (2015) Hf-Zr anomalies in clinopyroxene from France and Poland: implications for Lu-Hf dating of spinel peridotite lithospheric mantle. Int J Earth Sci 104:89-102

Frey FA, Green DH (1974) The mineralogy, geochemistry and origin of lherzolite inclusions in Victorian basanites. Geochim Cosmochim Acta 38:1023-1059

Frey FA, Prinz M (1978) Ultramafic inclusions from San Carlos, Arizona: petrologic and geochemical data bearing on their petrogenesis. Earth Planet Sc Lett 38:129-176

Griffin WL, O'Reilly SY, Ryan CG (1999) The composition and origin of sub-continental lithospheric mantle. In: Fei Y, Bertka CM, Mysen BJ (eds) Mantle petrology: field observations and high-pressure experimentations: a tribute to Francis R. (Joe) Boyd. The Geochemical Society Special Publications, Houston, pp 13-45

Hart SR, Dunn T (1993) Experimental cpx/melt partitioning of 24 trace elements. Contrib Mineral Petrol 113:1-8

Hellebrand E, Snow JE, Hoppe P, Hofmann AW (2002) Garnet-field melting and late-stage refertilization in 'residual' abyssal peridotites from the Central Indian Ridge. J Petrol 43:2305-2338

Hofmann AW (2007) 2.03 - Sampling mantle heterogeneity through oceanic basalts: isotopes and trace elements. In: Holland HD, Turekian KK (eds) Treatise on geochemistry. Elsevier, Amsterdam, pp 1-44

Ionov DA, Dupuy C, O'Reilly SY, Kopylova MG, Genshaft YS (1993) Carbonated peridotite xenoliths from Spitsbergen: implications for trace element signature of mantle carbonate metasomatism. Earth Planet Sc Lett 119:283-297

Ionov DA, Bodinier JL, Mukasa SB, Zanetti A (2002) Mechanisms and sources of mantle metasomatism: major and trace element compositions of peridotite xenoliths from Spitsbergen in the context of numerical modelling. J Petrol 43:2219-2259

Ionov DA, Prikhodko VS, Bodinier JL, Sobolev AV, Weis D (2005) Lithospheric mantle beneath the south-eastern Siberian craton: petrology of peridotite xenoliths in basalts from the Tokinsky Stanovik. Contrib Mineral Petrol 149:647-665

Ionov DA, Chazot G, Chauvel C, Merlet C, Bodinier J-L (2006) Trace element distribution in peridotite xenoliths from Tok, SE Siberian craton: a record of pervasive, multi-stage metasomatism in shallow refractory mantle. Geochim Cosmochim Acta 70:1231-1260

Jochum KP, Weis U, Stoll B, Kuzmin D, Yang Q, Raczek I, Jacob DE, Stracke A, Birbaum K, Frick DA, Gunther D, Enzweiler J (2011) 
Determination of reference values for NIST SRM 610-617 glasses following ISO guidelines. Geostand Geoanalytic Res 35:397-429

Kelemen P, Joyce D, Webster JD, Holloway JR (1990) Reaction between ultramafic rock and fractionating basaltic magma II. experimental investigation of reaction between olivine tholeiite and harzburgite at $1150-1050^{\circ}$ Cand $5 \mathrm{~kb}$. J Petrol 31:99-134

Kozdrój W, Krentz O, Opletal M (2001) Comments on the geological map Lausitz-Jizera-Karkonosze (without Cenozoic sediments), 1: 100 000. Remigraf Ltd, Warsaw, 64 pp

Lenoir X, Garrido CJ, Bodinier J-L, Dautria J-M (2000) Contrasting lithospheric mantle domains beneath the Massif Central (France) revealed by geochemistry of peridotite xenoliths. Earth Planet Sc Lett 181:359-375

Liang Y, Sun C, Yao L (2013) A REE-in-two-pyroxene thermometer for mafic and ultramafic rocks. Geochim Cosmochim Acta 102:246-260

Matusiak Małek M, Puziewicz J, Ntaflos T, Gregoire M, Benoit M, Klügel A (2014) Two contrasting lithologies in off-rift subcontinental lithospheric mantle beneath Central Europe-the Krzeniow (SW Poland) case study. J Petrol 55:1799-1828

Matusiak-Małek M, Puziewicz J, Ntaflos T, Gregoire M, Downes H (2010) Metasomatic effects in the lithospheric mantle beneath the NE Bohemian Massif: a case study of Lutynia (SW Poland) peridotite xenoliths. Lithos 117:49-60

McDonough WF, Sun SS (1995) The composition of the Earth. Chem Geol 120:223-253

Mercier JCC, Nicolas A (1975) Textures and fabrics of upper mantle peridotites as illustrated by xenoliths from basalts. J Petrol 16:454-487

Morimoto N (1989) Nomenclature of pyroxenes. Subcommittee on Pyroxenes, Commission on New Minerals and Mineral Names, International Mineralogical Association. Can Mineral 27:143-156

Morishita T, Arai S, Ishida Y, Tamura A, Gervilla F (2009) Constraints on the evolutionary history of aluminous mafic rocks in the Ronda peridotite massif (Spain) from trace-element composition of clinopyroxene and garnet. Geochem J 43:191-206

Müntener O, Kelemen PB, Grove TL (2001) The role of $\mathrm{H}_{2} \mathrm{O}$ during crystallization of primitive arc magmas under uppermost mantle conditions and genesis of igneous pyroxenites: an experimental study. Contrib Mineral Petrol 141:643-658

Norman MD (1998) Melting and metasomatism in the continental lithosphere: laser ablation ICPMS analysis of minerals in spinel lherzolites from eastern Australia. Contrib Mineral Petrol 130:240-255

Norman MD (2001) Applications of laser ablation ICPMS to the trace element geochemistry of basaltic magmas and mantle evolution. In: Sylvester P (ed) Laser-ablation-ICPMS in the earth sciences: principles and application. Mineralogical Association of Canada, St. Johns, pp 163-184

O'Connor TK, Edgar AD, Lloyd FE (1996) Origin of glass in quaternary mantle xenoliths from Meerfeldermaar, West Eifel, Germany: implications for enrichment in the lithospheric mantle. Mineralogic Assoc Can 34:187-200

O'Reilly S, Griffin WL (2013) Mantle metasomatism. In: Harlov D, Austrheim H (eds) Metasomatism and the chemical transformation of rock. Springer, Berlin, pp 471-533

Pearson DG, Canil D, Shirey SB, Heinrich DH, Karl KT (2003) Mantle samples included in volcanic rocks: xenoliths and diamonds. In: Carlson RW (ed) The mantle and the core, treatise on geochemistry, vol 2. Elsevier, Amsterdam, pp 171-275

Peslier A, Francis D, Ludden J (2002) The lithospheric mantle beneath continental margins: melting and melt-rock reaction in Canadian Cordillera xenolits. J Petrol 43:2013-2047

Pushkarev Y (2000) Altersbestimmung. In: Stanek KP, Renno AD, Jentsch K, Lindner H, Käppler R (eds) Interdisziplinäre Auswertung der Forschungsbohrung Baruth. Abschlussbericht zu einem Forschungs- und Entwicklungsvorhaben des LfUG, Geologisches Institut der TU BA, Freiberg, p 129

Puziewicz J, Koepke J, Grégoire M, Ntaflos T, Matusiak-Małek M (2011) Lithospheric mantle modification during Cenozoic rifting in Central
Europe: evidence from the Ksieginki nephelinite (SW Poland) xenolith suite. J Petrol 52:2107-2145

Puziewicz J, Matusiak-Małek M, Ntaflos T, Grégoire M, Kukuła A (2015) Subcontinental lithospheric mantle beneath Central Europe. IJES. doi:10.1007/s00531-014-1134-2

Rehfeldt T, Obst K, Johansson L (2007) Petrogenesis of ultramafic and mafic xenoliths from Mesozoic basanites in southern Sweden: constraints from mineral chemistry. Int J Earth Sci 96:433-450

Ringuette L, Martignole J, Windley BF (1999) Magmatic crystallization, isobaric cooling, and decompression of the garnet-bearing assemblages of the Jijal sequence (Kohistan terrane, western Himalayas). Geology 27:139-142

Rudnick RL, McDonough WF, Chappell BC (1993) Carbonatite metasomatism in the northern Tanzanian mantle. Earth Planet Sc Lett 114:463-475

Sawicki L (1995) Geological map of lower Silesia with adjacent Czech and German territories (without quaternary deposits). Polish Geological Institute, Warszawa

Seifert KE, Chadima SA (1989) Depletion of heavy rare-earth elements in metamorphic minerals from Adirondack anorthosites. Geology 17: 1004-1006

Shaw CSJ (1999) Dissolution of orthopyroxene in basanitic magma between 0.4 and $2 \mathrm{GPa}$ : further implications for the origin of Si-rich alkaline glass in mantle xenoliths. Contrib Mineral Petrol 135:114-132

Shaw CSJ (2009) Textural development of amphibole during breakdown reactions in a synthetic peridotite. Lithos 110:215-228

Shaw CSJ, Dingwell DB (2008) Experimental peridotite-melt reaction at one atmosphere: a textural and chemical study. Contrib Mineral Petrol 155:199-214

Shaw CSJ, Klügel A (2002) The pressure and temperature conditions and timing of glass formation in mantle-derived xenoliths from Baarley, West Eifel, Germany: the case for amphibole breakdown, lava infiltration and mineral - melt reaction. Miner Petrol 74:163-187

Shimizu Y, Arai S, Morishita T, Ishida Y (2008) Origin and significance of spinel-pyroxene symplectite in lherzolite xenoliths from Tallante, SE Spain. Miner Petrol 94:27-43

Tietz O, Büchner J, Suhr P, Goth K (2013) Field trip 3: Volcanology of the Lusatian Volcanic Field - New insights in old well-known. - In: Büchner J, Rapprich V, Tietz O (eds.): Abstracts \& Excursion Guides to the scientific conference "Basalt 2013 - Cenozoic Magmatism in Central Europe", Görlitz, 24.-28.4.2013, Czech Geological Survey; Prague: 275-297

Tursack E, Liang Y (2012) A comparative study of melt-rock reactions in the mantle: laboratory dissolution experiments and geological field observations. Contrib Mineral Petrol 163:861-876

Upton BGJ, Downes H, Kirstein LA, Bonadiman C, Hill PG, Ntaflos T (2011) The lithospheric mantle and lower crust-mantle relationships under Scotland: a xenolithic perspective. J Geol Soc 168:873-886

van Achterberg E, Ryan CG, Jackson SE, Griffin WL (2001) Data reduction software for LA-ICP-MS. In: Sylvester PJ (ed) Laser ablation ICPMS in the earth sciences, vol 29, Principles and Applications. mineralogical association of Canada, short course series., pp 239-243

Witt-Eickschen G, Kramm U (1998) Evidence for the multiple stage evolution of the subcontinental lithospheric mantle beneath the Eifel (Germany) from pyroxenite and composite pyroxenite/ peridotite xenoliths. Contrib Mineral Petrol 131:258-272

Witt-Eickschen G, Seck HA (1991) Solubility of Ca and Al in orthopyroxene from spinel peridotite: an improved version of an empirical geothermometer. Contrib Mineral Petrol 106:431-439

Yaxley GM, Crawford AJ, Green DH (1991) Evidence for carbonatite metasomatism in spinel peridotite xenoliths from Western Victoria, Australia. Earth Planet Sci Lett 107:305-317

Zangana NA, Downes H, Thirlwall MF, Hegner E (1997) Relationship between deformation, equilibration temperatures, REE and radiogenic isotopes in mantle xenoliths (Ray Pic, Massif Central, France): an example of plume-lithosphere interaction? Contrib Mineral Petrol 127:187-203 